\title{
Electron interaction with copper(II) carboxylate compounds
}

\author{
Michal Lacko ${ }^{1}$, Peter Papp ${ }^{* 1}$, Iwona B. Szymańska ${ }^{* 2}$, Edward Szłyk ${ }^{2}$ \\ and Štefan Matejčík ${ }^{1}$
}

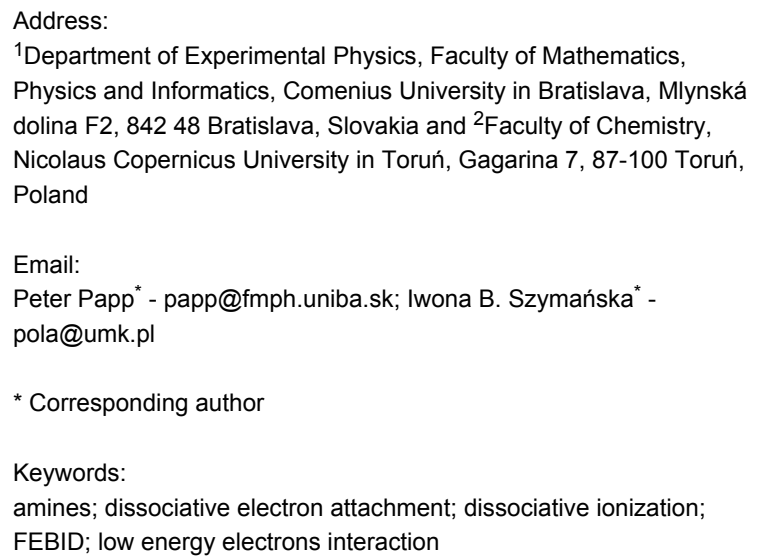

Beilstein J. Nanotechnol. 2018, 9, 384-398.

doi:10.3762/bjnano.9.38

Received: 29 June 2017

Accepted: 02 January 2018

Published: 01 February 2018

This article is part of the Thematic Series "Chemistry for electron-induced nanofabrication".

Guest Editor: P. Swiderek

(C) 2018 Lacko et al.; licensee Beilstein-Institut.

License and terms: see end of document.

\begin{abstract}
In the present study we have performed electron collision experiments with copper carboxylate complexes: $\left[\mathrm{Cu}_{2}\left(t-\mathrm{BuNH}_{2}\right)_{2}(\mu-\right.$ $\left.\left.\mathrm{O}_{2} \mathrm{CC}_{2} \mathrm{~F}_{5}\right)_{4}\right],\left[\mathrm{Cu}_{2}\left(s-\mathrm{BuNH}_{2}\right)_{2}\left(\mu-\mathrm{O}_{2} \mathrm{CC}_{2} \mathrm{~F}_{5}\right)_{4}\right],\left[\mathrm{Cu}_{2}\left(\mathrm{EtNH}_{2}\right)_{2}\left(\mu-\mathrm{O}_{2} \mathrm{CC}_{2} \mathrm{~F}_{5}\right)_{4}\right]$, and $\left[\mathrm{Cu}_{2}\left(\mu-\mathrm{O}_{2} \mathrm{CC}_{2} \mathrm{~F}_{5}\right)_{4}\right]$. Mass spectrometry was used to identify the fragmentation pattern of the coordination compounds produced in crossed electron - molecular beam experiments and to measure the dependence of ion yields of positive and negative ions on the electron energy. The dissociation pattern of positive ions contains a sequential loss of both the carboxylate ligands and/or the amine ligands from the complexes. Moreover, the fragmentation of the ligands themselves is visible in the mass spectrum below $m / z 140$. For the studied complexes the metallated ions containing both ligands, e.g., $\mathrm{Cu}_{2}\left(\mathrm{O}_{2} \mathrm{CC}_{2} \mathrm{~F}_{5}\right)\left(\mathrm{RNH}_{2}\right)^{+}, \mathrm{Cu}_{2}\left(\mathrm{O}_{2} \mathrm{CC}_{2} \mathrm{~F}_{5}\right)_{3}\left(\mathrm{RNH}_{2}\right)_{2}{ }^{+}$confirm the evaporation of whole complex molecules. A significant production of $\mathrm{Cu}^{+}$ion was observed only for $\left[\mathrm{Cu}_{2}\left(\mu-\mathrm{O}_{2} \mathrm{CC}_{2} \mathrm{~F}_{5}\right)_{4}\right]$, a weak yield was detected for $\left[\mathrm{Cu}_{2}\left(\mathrm{EtNH}_{2}\right)_{2}\left(\mu-\mathrm{O}_{2} \mathrm{CC}_{2} \mathrm{~F}_{5}\right)_{4}\right]$ as well. The dissociative electron attachment processes leading to formation of negative ions are similar for all investigated molecules as the highest unoccupied molecular orbital of the studied complexes has $\mathrm{Cu}-\mathrm{N}$ and $\mathrm{Cu}-\mathrm{O}$ antibonding character. For all complexes, formation of the $\mathrm{Cu}_{2}\left(\mathrm{O}_{2} \mathrm{CC}_{2} \mathrm{~F}_{5}\right)_{4}{ }^{-\bullet}$ anion is observed together with mononuclear DEA fragments $\mathrm{Cu}\left(\mathrm{O}_{2} \mathrm{CC}_{2} \mathrm{~F}_{5}\right)_{3}{ }^{-}, \mathrm{Cu}\left(\mathrm{O}_{2} \mathrm{CC}_{2} \mathrm{~F}_{5}\right)_{2}{ }^{-}$and $\mathrm{Cu}_{2}\left(\mathrm{O}_{2} \mathrm{CC}_{2} \mathrm{~F}_{5}\right)^{-\bullet}$. All dominant DEA fragments of these complexes are formed through single particle resonant processes close to $0 \mathrm{eV}$.
\end{abstract}

\section{Introduction}

Present technological changes require the development of new methods and new materials for preparation of thin layers or 3D nanostructures. Complexes and metalorganic compounds are used as precursors in modern nano scale layer techniques. After activation, molecules undergo dissociation on the surface. Volatile parts of molecules are removed from the surface while a metal component remains and forms the layer. Activation of the precursor molecules can be induced by several processes. For 
instance, a catalytic or a thermal dissociation can occur. Plasma activated processes such as plasma enhanced chemical vapor deposition (PECVD) can be used for coating of the surface [1] In the latter, reactive chemical species (radicals) and electrons lead to activation of molecules and this process can be controlled well on large scales.

One of the most innovative techniques, known as EBID or FEBID (Focused Electron Beam Induced Deposition) [2,3], uses a high energy electron beam that can be focused into a spot of diameter in the nanometer range for a spatially confined activation of precursor molecules on a very narrow range of the surface. The presence of high energy electrons from the primary beam (usually around $10 \mathrm{keV}$ ) causes ionization inside the wafer, with a high yield of secondary low energy electrons (below $100 \mathrm{eV}$ ). These electrons can diffuse to the surface and initiate reactions in the precursor molecules. As a result, a deposit is formed. This technique enables the production of free standing 3D nanostructures and is already used commercially for the repair of photolithographic masks $[4,5]$.

However, the underlying chemical reactions on the surface are still not well known. Moreover, the main problems of FEBID are co-deposited impurities resulting from incomplete dissociation of the precursor molecules. The level of purity strongly depends on the type of the precursor molecule. Only a few types of precursors are known to produce a layer with purity over $80 \%$ [3]. Moreover, there is no clear connection between the layer purity and the type of ligand in the precursor; an iron deposit from $\mathrm{Fe}(\mathrm{CO})_{5}$ leads to purity over $95 \%$ of $\mathrm{Fe}$, while tungsten layers from $\mathrm{W}(\mathrm{CO})_{6}$ can reach purities of $\mathrm{W}$ from 55 to $70 \%[6,7]$. For comparison, the deposition of cobalt from $\mathrm{Co}(\mathrm{CO})_{3}(\mathrm{NO})$ leads to around $50 \%$ purity [8] or satisfying purity over $95 \%$ using the dimer $\mathrm{Co}_{2}(\mathrm{CO})_{8}$ [9]. Only few types of precursor molecules can be converted into a layer with satisfying level of purity, for other elements there is still demand for new precursors with other satisfactory parameters like vapor pressure, toxicity, thermal stability, and stability over time.

Electrons present on the surface are combination of high energy electrons from the primary electron beam and secondary electrons emitted from the surface. High energy electrons have low interaction cross section with the target molecule; their interaction efficiency is therefore very low. Secondary electrons, on the other hand, play important role through electron attachment (EA), dissociative electron attachment (DEA) [10-16] and electron ionization (EI), dissociative ionization (DI) [17-19] processes. Their kinetic energy is only a few eV, with energy distribution determined by the type of wafer and energy of primary beam $[20,21]$. Thorman et al. have compared gas phase and surface data on low energy electron interactions with some commonly used FEBID precursors [22] and have shown that in some cases a single ligand loss dominates the initial fragmentation following electron induced ionization or attachment. This may then induce other surface interactions. They also conclude that dissociation through neutral dissociations induced via electron impact excitation [23] can be as important as DEA.

Copper is an important material commonly used in the advanced metallization of microelectronic and optoelectronic devices and ultralarge-scale integrated (ULSI) circuits due to its low electrical resistivity, high stress-induced deformation, and electromigration resistance which is higher than for aluminum [24-27]. Copper nanostructures, especially nanowires, are applied in opto-electronic devices, solar cells, field-emission displays, catalysis, electronic skins, and sensor devices. Moreover, they can find medical applications because copper exhibits antibacterial and antifungal properties [28].

In FEBID experiments, the deposited $\mathrm{Cu}-\mathrm{C}$ lines and squares, obtained from the fluorinated copper(II) $\beta$-diketonate $\left[\mathrm{Cu}(\mathrm{hfac})_{2}\right]$, had an atomic ratio of approximately $\mathrm{Cu} / \mathrm{C} / \mathrm{O} / \mathrm{F}=\mathbf{1 0}: 64: 25: 1$. In materials obtained using other copper(I) $\beta$-diketonate complexes, namely, [Cu(hfac)VTMS], $[\mathrm{Cu}(\mathrm{hfac}) \mathrm{DMB}]$, and $[\mathrm{Cu}(\mathrm{hfac}) \mathrm{MHY}]$ the atomic ratios of Cu/C/O/Si were 20-45:35-70:8-14:2-10, 25-60:15-60:5-25:-, and 13:82:3:-, respectively. As-deposited freestanding rods from FEBID experiments with [Cu(hfac)VTMS] showed small $\mathrm{Cu}$ nanocrystals dispersed in a polymeric carbonaceous matrix, which contains all the ligand elements: carbon, oxygen, fluorine and silicone $[29,30]$.

Therefore, new copper FEBID precursors are still necessary. When designing such new precursors, it should be considered that copper(II) derivatives are more user-friendly than copper(I) compounds, which are usually air and moisture sensitive, which results in decomposition of the precursor itself. Also, introduction of amine ligands was expected to be advantageous. In fact, the reducing action of ammine ligands was discussed previously with respect to FEBID experiments using cisplatin $\left[\mathrm{Pt}\left(\mathrm{NH}_{3}\right)_{2} \mathrm{Cl}_{2}\right]$ as precursor [31]. These latter experiments were motivated by gas phase DEA studies on this compound showing also that it can be evaporated intact [32].

Electron impact $\mathrm{MS}$ spectra analysis of $\left[\mathrm{Cu}\left(\mathrm{O}_{2} \mathrm{CR}\right)_{2}\right]$ $\left(\mathrm{R}=\mathrm{C}_{n} \mathrm{H}_{2 n-1}, n=1-3 ; \mathrm{CF}_{3}, \mathrm{CHF}_{2}, \mathrm{C}_{6} \mathrm{H}_{5}, \mathrm{p}-\mathrm{F}-\mathrm{C}_{6} \mathrm{H}_{4}, \mathrm{p}-\mathrm{Cl}-\right.$ $\left.\mathrm{C}_{6} \mathrm{H}_{4}, \mathrm{o}-\mathrm{Cl}-\mathrm{C}_{6} \mathrm{H}_{4}, \mathrm{C}_{6} \mathrm{~F}_{5}\right)$ [33] and $\left[\mathrm{Cu}_{2}\left(t-\mathrm{BuNH}_{2}\right)_{2}\left(\mu-\mathrm{O}_{2} \mathrm{CR}\right)_{4}\right]$ ( $\left.\mathrm{R}=\mathrm{C}_{n} \mathrm{~F}_{2 n-1}, n=1-6\right)$ [34] investigated previously suggested that copper(II) easily changes its oxidation state to $\mathrm{Cu}$ (I) in the gas phase and the highest intensity was observed for the fragment $\mathrm{Cu}_{2}\left(\mathrm{O}_{2} \mathrm{CR}\right)^{+}$. On the other hand, copper(I) compounds 
spontaneously disproportionate to copper(II) derivatives and copper(0), which can form the deposit.

Gas phase electron-precursor collision experiments should allow to determine the potential usefulness of new compounds in FEBID. Moreover, these results can be interesting for the development of new metalorganic or coordination compounds suitable for FEBID.

Previous gas phase studies performed in Bratislava with coordination compounds have shown the importance of DI and DEA processes in FEBID [10-12,17-19,35]. The partial decomposition of the metal complex via DI and DEA together with the role of secondary electrons in FEBID acting on much wider range than is the focus of the primary beam leads to broadening of the deposited structure [36]. The importance of the DI and/or DEA processes in FEBID was also discussed by Warneke et al. [37] with the focus on the appropriate choice of the ligands on the metal complex. In this work, acetylacetone was studied under electron impact and it was concluded from gas phase experiments that radicals released by electron-induced fragmentation react with intact molecules to produce a non-volatile residue that was detected using XPS. These results emphasize that both the proper choice of ligands and the knowledge of elementary processes under DI and DEA in gas phase are important for the understanding and development of FEBID precursors.

In the present experiments electron impact ionization, electron attachment, and subsequent dissociation processes have been studied for the first time on the following copper(II) pentafluoropropionate derivatives: $\left[\mathrm{Cu}_{2}\left(t-\mathrm{BuNH}_{2}\right)_{2}\left(\mu-\mathrm{O}_{2} \mathrm{CC}_{2} \mathrm{~F}_{5}\right)_{4}\right]$, $\left[\mathrm{Cu}_{2}\left(s-\mathrm{BuNH}_{2}\right)_{2}\left(\mu-\mathrm{O}_{2} \mathrm{CC}_{2} \mathrm{~F}_{5}\right)_{4}\right],\left[\mathrm{Cu}_{2}\left(\mathrm{EtNH}_{2}\right)_{2}\left(\mu-\mathrm{O}_{2} \mathrm{CC}_{2} \mathrm{~F}_{5}\right)_{4}\right]$, and $\left[\mathrm{Cu}_{2}\left(\mu-\mathrm{O}_{2} \mathrm{CC}_{2} \mathrm{~F}_{5}\right)_{4}\right]$ (Figure 1).
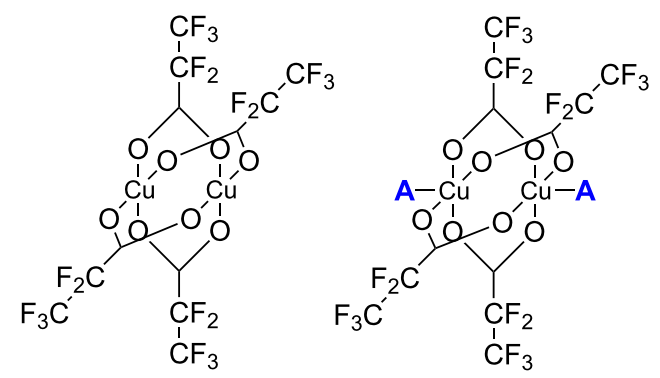

Figure 1: A schematic structure of investigated molecules (left) $\left[\mathrm{Cu}_{2}(\mu\right.$ $\left.\left.\mathrm{O}_{2} \mathrm{CC}_{2} \mathrm{~F}_{5}\right)_{4}\right]$, (right) $\left[\mathrm{Cu}_{2}\left(\mathrm{EtNH}_{2}\right)_{2}\left(\mu-\mathrm{O}_{2} \mathrm{CC}_{2} \mathrm{~F}_{5}\right)_{4}\right],\left[\mathrm{Cu}_{2}\left(t-\mathrm{BuNH}_{2}\right)_{2}(\mu-\right.$ $\left.\left.\mathrm{O}_{2} \mathrm{CC}_{2} \mathrm{~F}_{5}\right)_{4}\right]$, and $\left.\mathrm{Cu}_{2}\left(s-\mathrm{BuNH}_{2}\right)_{2}\left(\mu-\mathrm{O}_{2} \mathrm{CC}_{2} \mathrm{~F}_{5}\right)_{4}\right]$, where $\mathrm{A}$ represent different amine ligands.

The carboxylate copper(II) complexes with tert-butylamine $\left(\left[\mathrm{Cu}_{2}\left(t-\mathrm{BuNH}_{2}\right)_{2}\left(\mu-\mathrm{O}_{2} \mathrm{CR}\right)_{4}\right]\right.$, where $\left.\mathrm{R}=\mathrm{C}_{n} \mathrm{~F}_{2 n+1}, n=1-6\right)$ were previously applied as $\mathrm{Cu} C V D$ precursors $[34,38]$ for the formation of copper nanomaterials. This fact confirms that copper(II) carboxylate compounds can be considered as copper sources in vapor deposition processes. The influence of secondary ligands on the physicochemical properties and, with regards to FEBID, the electron-induced fragmentation behaviour of pentafluoropropionate $\mathrm{Cu}(\mathrm{II})$ complexes as studied here is thus of particular interest.

\section{Results}

\section{Mass spectrum of $\left[\mathrm{Cu}_{2}\left(\mu-\mathrm{O}_{2} \mathrm{CC}_{2} \mathrm{~F}_{5}\right)_{4}\right]$}

$\left[\mathrm{Cu}_{2}\left(\mu-\mathrm{O}_{2} \mathrm{CC}_{2} \mathrm{~F}_{5}\right)_{4}\right]$ represents the basic chemical structure for all discussed carboxylate compounds in this work. In Figure 2 the fragmentation pattern of $\left[\mathrm{Cu}_{2}\left(\mu-\mathrm{O}_{2} \mathrm{CC}_{2} \mathrm{~F}_{5}\right)_{4}\right]$ is presented. The spectrum was obtained with higher mass resolution at which it is easy to resolve to atomic masses for $\mathrm{m} / \mathrm{z}$ from 10 to 150. For $\mathrm{m} / \mathrm{z}$ from 150 up to 800 lower mass resolution was used to increase the signal intensity. Some of the peaks obtained at low resolution but with satisfying intensity were re-measured with higher resolution again.

The parent ion $\mathrm{Cu}_{2}\left(\mu-\mathrm{O}_{2} \mathrm{CC}_{2} \mathrm{~F}_{5}\right)_{4}{ }^{+\cdot}$ has been detected at $\mathrm{m} / \mathrm{z}$ 788. Its electron induced dissociation can be characterized by several fragmentation patterns. The first is the sequential loss of the ligand radical $\mathrm{O}_{2} \mathrm{C}-\mathrm{C}_{2} \mathrm{~F}_{5}(\mathrm{~L})$, which is characterized by formation of $\mathrm{Cu}_{2} \mathrm{~L}_{3}{ }^{+}, \mathrm{Cu}_{2} \mathrm{~L}_{2}{ }^{+\bullet}$, and $\mathrm{Cu}_{2} \mathrm{~L}^{+}$ions up to a final decomposition to the copper dinuclear $\mathrm{Cu}_{2}^{+\bullet}$ and the $\mathrm{Cu}^{+}$ion as well. Another pattern results from the fragmentation of the $\mathrm{O}_{2} \mathrm{C}-\mathrm{C}_{2} \mathrm{~F}_{5}$ ligand itself, as can be seen for the $\mathrm{C}-\mathrm{C}$ bond dissociation between the $\mathrm{CO}_{2}$ and $\mathrm{C}_{2} \mathrm{~F}_{5}$ units. The rupture of this bond in the coordinated carboxylate gives rise to the $\mathrm{Cu}_{2}(\mathrm{~L})\left(\mathrm{O}_{2} \mathrm{C}\right)^{+}$ion. The remaining products are formed via additional fragmentation of the ligand or rearrangement of some of its atoms, e.g., $\mathrm{Cu}_{2} \mathrm{CF}_{3}{ }^{+}$. Moreover, we have identified the simultaneous $\mathrm{C}-\mathrm{F}$ and $\mathrm{C}-\mathrm{C}$ bond dissociation via fragmentation of neutral tetrafluoroethene $\left(\mathrm{C}_{2} \mathrm{~F}_{4}\right)$ from the complex, while the remaining fluorine atom is bound in $\mathrm{Cu}_{2} \mathrm{~F}^{+}$. Finally, the formation of the $\mathrm{Cu}^{+}$ion has been observed only in the mass spectrum at higher temperature $\left(150{ }^{\circ} \mathrm{C}\right)$ of the molecular beam source. This copper fragment abundance achieved the highest value among signals registered below $\mathrm{m} / \mathrm{z} 300$. Over this $\mathrm{m} / \mathrm{z}$ range the signal intensity is not reduced by the QMS (Experimental).

Additionally, we have seen tricopper $\mathrm{Cu}_{3} \mathrm{LO}^{+}(\mathrm{m} / z$ 368) and $\mathrm{Cu}_{3} \mathrm{O}^{+}(m / z 205)$ ions. The formation of tricopper ionic fragments could be a consequence of structural units containing three $\mathrm{Cu}$ atoms in the solid phase of $\left[\mathrm{Cu}_{2}\left(\mu-\mathrm{O}_{2} \mathrm{CR}\right)_{4}\right]$. These can be formed via a possible interaction of oxygen atoms and copper atoms of two neighbouring dinuclear structures. The $\mathrm{X}$-ray crystal structure of studied compound is still unresolved 


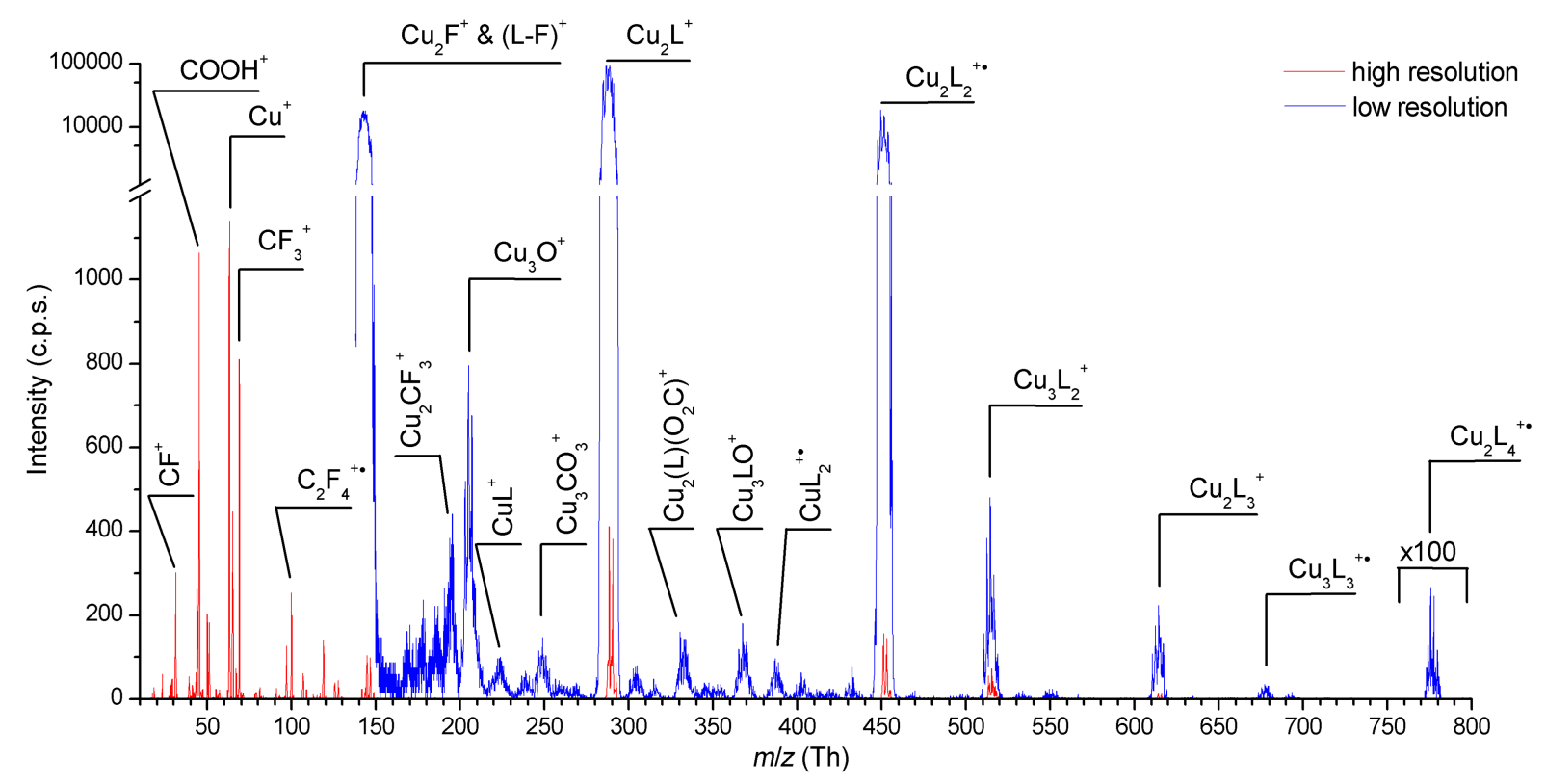

Figure 2: Mass spectrum of $\left[\mathrm{Cu}_{2}\left(\mu-\mathrm{O}_{2} \mathrm{CC}_{2} \mathrm{~F}_{5}\right)_{4}\right]$ molecule over the range $\mathrm{m} / \mathrm{z} 10-800$ obtained at electron energy $70 \mathrm{eV}$ and temperature of the beam source of $\approx 150{ }^{\circ} \mathrm{C}$. The notation $\mathrm{L}=\mathrm{O}_{2} \mathrm{CC}_{2} \mathrm{~F}_{5}$ was used in the mass spectrum. The spectral range below $\mathrm{m} / \mathrm{z} 150$ and selected peaks at higher masses were measured with higher mass resolution (red line) while the range above $\mathrm{m} / \mathrm{z} 150$ was registered with lower resolution (blue line) to increase the signal.

but the trinuclear (or more complicated) structures for copper(II) carboxylates were observed [39-41].

The presence of a ligand cation $\mathrm{O}_{2} \mathrm{CC}_{2} \mathrm{~F}_{5}{ }^{+}\left(\mathrm{L}^{+}\right)$has not been confirmed in the positive ion mass spectrum of $\left[\mathrm{Cu}_{2}(\mu\right.$ $\left.\mathrm{O}_{2} \mathrm{CC}_{2} \mathrm{~F}_{5}\right)_{4}$ ], in contrast to the DEA spectra (see below) where $\mathrm{L}^{-}$was formed. In the $\left[\mathrm{Cu}_{2}\left(\mu-\mathrm{O}_{2} \mathrm{CC}_{2} \mathrm{~F}_{5}\right)_{4}\right]$ mass spectrum the formation of the pentafluoroethyl ion $\left(\mathrm{C}_{2} \mathrm{~F}_{5}{ }^{+}\right)$was observed, which further dissociated to $\mathrm{C}_{2} \mathrm{~F}_{4}{ }^{+\bullet}, \mathrm{CF}_{3}{ }^{+}, \mathrm{CF}_{2}{ }^{+}$, and $\mathrm{CF}^{+}$ions. The complementary reaction is the formation of the $\mathrm{CO}_{2}^{+}$ cation.

An unusual product in the mass spectrum of this molecule can be seen at $m / z 45$, which is according to our conclusions the $\mathrm{COOH}^{+}$ion. The only explanation for the formation of this product from a sample without any hydrogen atom is the interaction between $\left[\mathrm{Cu}_{2}\left(\mu-\mathrm{O}_{2} \mathrm{CC}_{2} \mathrm{~F}_{5}\right)_{4}\right]$ and adsorbed water traces. The possibility that the $\left[\mathrm{Cu}_{2}\left(\mu-\mathrm{O}_{2} \mathrm{CC}_{2} \mathrm{~F}_{5}\right)_{4}\right]$ sample was contaminated by some free acid was excluded.

Appearance energies have been measured for several fragments (Figure 3). The values presented in Table 1 are estimated with uncertainty $\pm 0.5 \mathrm{eV}$, which results from the resolution of the electron beam that varied from $100 \mathrm{meV}$ up to $500 \mathrm{meV}$. The largest value was taken to estimate the margin of error. The resolution of the electron beam was lowered to increase the electron current and ion yields when the sample has adsorbed on the electrodes of the monochromator and thus affected their electric fields. The appearance energy for the ion with $\mathrm{m} / z 18$ is $A E_{18}=12.6 \mathrm{eV}$ and is in a good agreement with the ionization energy of the water molecule, $\operatorname{IE}\left(\mathrm{H}_{2} \mathrm{O}\right)=12.62 \mathrm{eV}$ [42]. It cannot be produced from $\left[\mathrm{Cu}_{2}\left(\mu-\mathrm{O}_{2} \mathrm{CC}_{2} \mathrm{~F}_{5}\right)_{4}\right]$ itself due to its lack of hydrogen atoms; obviously must have desorbed from the sample. This is in agreement with the presence of the previously discussed $\mathrm{COOH}^{+}$ion that is assumed to be formed via interaction of residual water molecules with the sample.

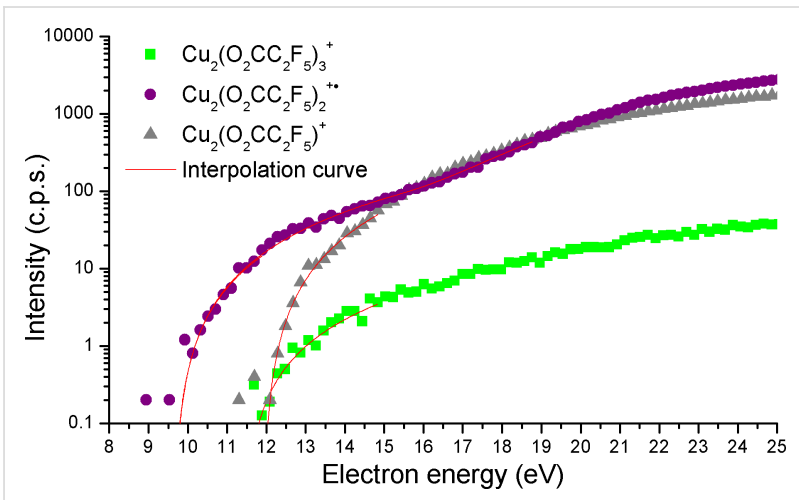

Figure 3: Relative cross sections of the dissociative ionization of the $\left[\mathrm{Cu}_{2}\left(\mu-\mathrm{O}_{2} \mathrm{CC}_{2} \mathrm{~F}_{5}\right)_{4}\right]$ molecule as a result of a ligand loss fragmentation process. Red lines represent a theoretical fits using the modified Wannier formula. 


\begin{tabular}{|c|c|c|c|c|c|c|c|}
\hline $\mathrm{m} / \mathrm{z}$ & Ion & $A E^{1}[\mathrm{eV}]$ & $A E^{2}[\mathrm{eV}]$ & $\mathrm{m} / \mathrm{z}$ & Ion & $A E^{1}[\mathrm{eV}]$ & $A E^{2}[\mathrm{eV}]$ \\
\hline 18 & $\mathrm{H}_{2} \mathrm{O}^{+\cdot}$ & $12.6^{a}$ & & 145 & $\mathrm{Cu}_{2} \mathrm{~F}^{+}$ & $15.9^{a}$ & \\
\hline 31 & $\mathrm{CF}^{+}$ & $11.0^{\mathrm{a}}$ & $18.3^{b}$ & 289 & $\mathrm{Cu}_{2} \mathrm{~L}^{+}$ & $11.9^{a}$ & \\
\hline 45 & $\mathrm{COOH}^{+}$ & $13.5^{\mathrm{a}}$ & & 370 & $\mathrm{Cu}_{3} \mathrm{LO}^{+}$ & $25.7^{c}$ & \\
\hline 50 & $\mathrm{CF}_{2}{ }^{+}$ & $14.4^{a}$ & & 452 & $\mathrm{Cu}_{2} \mathrm{~L}_{2}{ }^{+\cdot}$ & $09.7^{a}$ & $15.2^{\mathrm{b}}$ \\
\hline 63 & $\mathrm{Cu}^{+}$ & $15.7^{a}$ & & 515 & $\mathrm{Cu}_{3} \mathrm{~L}_{2}^{+}$ & $16.1^{\mathrm{a}}$ & \\
\hline 69 & $\mathrm{CF}_{3}^{+}$ & $11.7^{\mathrm{a}}$ & $16.1^{a}$ & 615 & $\mathrm{Cu}_{2} \mathrm{~L}_{3}{ }^{+}$ & $11.4^{\mathrm{a}}$ & $15.7^{b}$ \\
\hline 100 & $\mathrm{C}_{2} \mathrm{~F}_{4}^{+\cdot}$ & $12.2^{\mathrm{a}}$ & & 678 & $\mathrm{Cu}_{3} \mathrm{~L}_{3}{ }^{+\cdot}$ & $15.7^{a}$ & \\
\hline 119 & $\mathrm{C}_{2} \mathrm{~F}_{5}^{+}$ & $15.1^{a}$ & & & & & \\
\hline
\end{tabular}

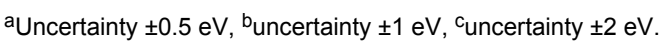

Dissociation of first carboxylate ligand from $\left[\mathrm{Cu}_{2}(\mu\right.$ $\left.\left.\mathrm{O}_{2} \mathrm{CC}_{2} \mathrm{~F}_{5}\right)_{4}\right]$ molecule was detected with $A E^{1}{ }_{615}=11.4 \mathrm{eV}$ and with a second threshold at $A E^{2}{ }_{615}=15.7 \mathrm{eV}$. Dissociation of second ligand occurs with $A E^{1} 452=9.7 \mathrm{eV}$ and again with a second threshold at $A E^{2}{ }_{452}=15.2 \mathrm{eV}$. Dissociation of third ligand starts at $A E_{289}=11.9 \mathrm{eV}$ without any other distinguishable threshold. The origin of the second threshold can be a) an energetically higher excited state of the same fragment, b) a different stoichiometric fragment or c) a different energetically higher process, or doubly charged product. We did not find any other stoichiometric product for the given masses so the existence of an excited ionic state is the reasonable explanation. An interesting fact is that the loss of two ligands requires less energy than the dissociation of first and third ligand.

As mentioned before we did not observe any signal for a ligand cation itself, therefore we did not obtain any $A E$ value for its production. A decreasing trend of $A E$ for $\mathrm{C}_{\mathrm{x}} \mathrm{F}_{\mathrm{y}}$ fragments was found: $A E_{119}=15.1 \mathrm{eV}, A E_{100}=12.2 \mathrm{eV}, A E_{69}=11.7 \mathrm{eV}$, $A E_{31}=11.0 \mathrm{eV}$ except of $\mathrm{CF}_{2}{ }^{+}$ion $(\mathrm{m} / \mathrm{z} 50)$ that clearly requires additional energy for dissociation of $\mathrm{F}$ atom from $\mathrm{CF}_{3}{ }^{+}$ ion. Ion $\mathrm{COOH}^{+}$with $\mathrm{m} / \mathrm{z} 45$ proposed as an impurity has $A E_{45}=13.5 \mathrm{eV}$, which is however much higher than the ionization energy of hydrocarboxyl radical $I E(\mathrm{COOH})=8.2 \mathrm{eV}$ [43]. According to our conclusions its formation is accompanied by dissociation of two $\mathrm{Cu}-\mathrm{O}$ bonds and a $\mathrm{C}-\mathrm{C}$ bond on the complex as well as $\mathrm{O}-\mathrm{H}$ bond dissociation on the water molecule.

\section{Mass spectra of $\left[\mathrm{Cu}_{2}\left(\mathrm{RNH}_{2}\right)_{2}\left(\mu-\mathrm{O}_{2} \mathrm{CC}_{2} \mathrm{~F}_{5}\right)_{4}\right]$ complexes}

Compared to $\left[\mathrm{Cu}_{2}\left(\mu-\mathrm{O}_{2} \mathrm{CC}_{2} \mathrm{~F}_{5}\right)_{4}\right]$, the fragmentation pattern of $\left[\mathrm{Cu}_{2}\left(\mathrm{EtNH}_{2}\right)_{2}\left(\mu-\mathrm{O}_{2} \mathrm{CC}_{2} \mathrm{~F}_{5}\right)_{4}\right]$ (Figure 4 ) is strongly affected by the presence of two ethylamine ligands and contains a combination of losses of both types of ligands. The parent ion was not detected and the highest mass signal $(\mathrm{m} / \mathrm{z}$ 704) for the $\mathrm{Cu}_{2} \mathrm{~L}_{3} \mathrm{~A}_{2}{ }^{+}$(A - amine ligand) fragment was observed. The detachment of the first, second as well as third carboxylate ligand is usually accompanied by the loss of the ethylamine ligand forming $\mathrm{Cu}_{2} \mathrm{~L}_{\mathrm{x}} \mathrm{A}^{+}$. The loss of the second ethylamine is present only for dissociation of two $\left(\mathrm{Cu}_{2} \mathrm{~L}_{2}{ }^{+\bullet} \mathrm{m} / z\right.$ 452) or three $\left(\mathrm{Cu}_{2} \mathrm{~L}^{+} \mathrm{m} / z\right.$ 289) carboxylate ligands from the complex but not for one only. Finally, dissociation of all carboxylate ligands has been observed with the dicopper system disconnection forming the $\mathrm{CuA}_{2}{ }^{+}$and $\mathrm{CuA}^{+}$ions ( $m / z 153$ and 108). As in the case of $\left[\mathrm{Cu}_{2}\left(\mu-\mathrm{O}_{2} \mathrm{CC}_{2} \mathrm{~F}_{5}\right)_{4}\right]$ discussed before, the fragmentation of the coordinated ligands themselves has been observed creating, e.g., $\mathrm{Cu}_{2} \mathrm{LA}(\mathrm{CO})^{+} / \mathrm{Cu}_{2} \mathrm{LA}\left(\mathrm{NH}_{2} \mathrm{CH}\right)^{+}, \mathrm{CuA}\left(\mathrm{O}_{2} \mathrm{C}\right)^{+}$. The $\mathrm{Cu}_{3}{ }^{+}$ fragment is also detected. We propose that the $\left[\mathrm{Cu}_{2}\left(\mathrm{EtNH}_{2}\right)_{2}(\mu-\right.$ $\left.\left.\mathrm{O}_{2} \mathrm{CC}_{2} \mathrm{~F}_{5}\right)_{4}\right]$ complex partly loses the amine ligand (A) when it is heated in vacuum chamber and forms the structure similar to $\left[\mathrm{Cu}_{2}\left(\mu-\mathrm{O}_{2} \mathrm{CC}_{2} \mathrm{~F}_{5}\right)_{4}\right]$. The formation of tricopper complex via copper oxygen interaction of two neighboring molecules can occur as was already discussed above for the $\left[\mathrm{Cu}_{2}(\mu-\right.$ $\left.\mathrm{O}_{2} \mathrm{CC}_{2} \mathrm{~F}_{5}\right)_{4}$ ] compound.

The dissociation of the carboxylate ligand is again visible in the mass spectrum, but not dominant anymore. Series of peaks at $\mathrm{m} / \mathrm{z} 30$ and $\mathrm{m} / \mathrm{z} 45$ uncover the preferable dissociation through ethylamine ligand fragmentation. A peak at $\mathrm{m} / \mathrm{z} 44$ can be assigned to $\mathrm{CO}_{2}^{+\bullet}$ or the $(\mathrm{A}-\mathrm{H})^{+}$ion. The abundance of the $\mathrm{CO}_{2}{ }^{+\bullet}$ ion released from described above $\left[\mathrm{Cu}_{2}\left(\mu-\mathrm{O}_{2} \mathrm{CC}_{2} \mathrm{~F}_{5}\right)_{4}\right]$ is comparable with other fragments of carboxylate ligand. However, in the case of $\left[\mathrm{Cu}_{2}\left(\mathrm{EtNH}_{2}\right)_{2}\left(\mu-\mathrm{O}_{2} \mathrm{CC}_{2} \mathrm{~F}_{5}\right)_{4}\right]$, the abundances of amine fragments (e.g., $\mathrm{C}_{2} \mathrm{H}_{6}{ }^{+} / \mathrm{CH}_{2} \mathrm{NH}_{2}{ }^{+}$) were changing in the same manner as for $m / z 44$ and in opposite to the fluorinecontaining fragments of the carboxylate ligand. These facts suggest that $m / z 44$ relates to the formation of $(\mathrm{A}-\mathrm{H})^{+}$. Moreover, in comparison with $\left[\mathrm{Cu}_{2}\left(\mu-\mathrm{O}_{2} \mathrm{CC}_{2} \mathrm{~F}_{5}\right)_{4}\right]$, the creation of the pure copper ion is strongly suppressed.

Similar to the ethylamine complex, the dissociation pattern of both $\left[\mathrm{Cu}_{2}\left(t-\mathrm{BuNH}_{2}\right)_{2}\left(\mu-\mathrm{O}_{2} \mathrm{CC}_{2} \mathrm{~F}_{5}\right)_{4}\right]$ and $\left[\mathrm{Cu}_{2}\left(s-\mathrm{BuNH}_{2}\right)_{2}(\mu-\right.$ $\left.\left.\mathrm{O}_{2} \mathrm{CC}_{2} \mathrm{~F}_{5}\right)_{4}\right]$ (Figure 5) is characterized by a lack of parent 


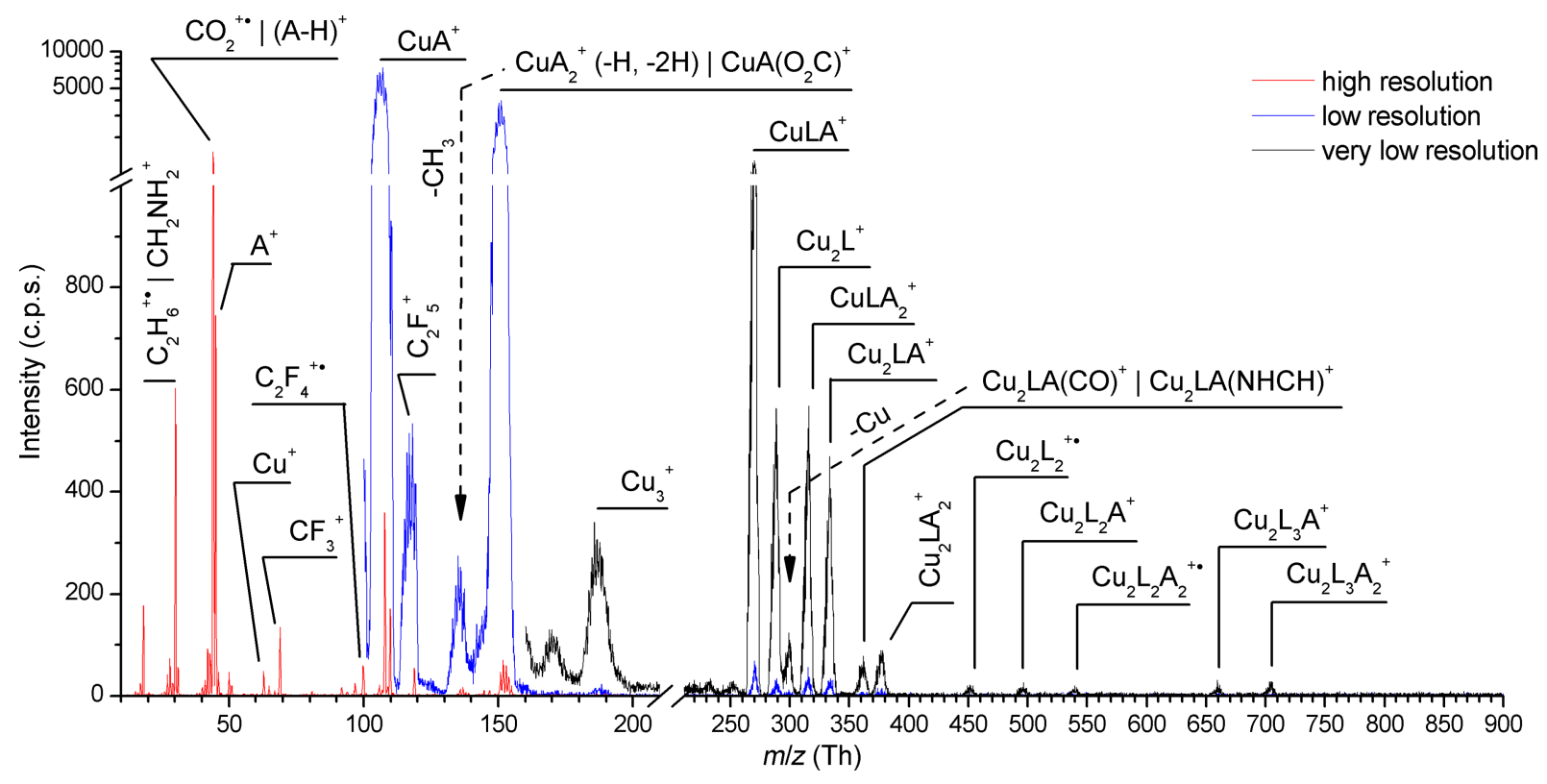

Figure 4: Mass spectrum of $\left[\mathrm{Cu}_{2}\left(\mathrm{EtNH}_{2}\right)_{2}\left(\mu-\mathrm{O}_{2} \mathrm{CC}_{2} \mathrm{~F}_{5}\right)_{4}\right]$ molecule over the range $\mathrm{m} / \mathrm{z} 10-900$ obtained at electron energy $70 \mathrm{eV}$ and temperature of the beam source of $\approx 80^{\circ} \mathrm{C}$. The spectral range below $\mathrm{m} / \mathrm{z} 200$ was measured with higher mass resolution (red line), while that range above $\mathrm{m} / \mathrm{z} 100$ (blue line) and above $\mathrm{m} / \mathrm{z} 160$ (black line) was measured with lower mass resolutions to increase the signal.

cation. The highest visible mass (for details Experimental) for both molecules is produced via detachment of one carboxylate ligand $\left(\mathrm{Cu}_{2} \mathrm{~L}_{3} \mathrm{~A}_{2}^{+}\right)$. As discussed before for the previous molecules, the range of the ions formed by whole carboxylate or amine ligand loss was registered. They appear for both tertbutyl and sec-butyl substituents above mass $m / z 130$ (Figure 5). We can recognize dicopper fragments, e.g., $\mathrm{Cu}_{2} \mathrm{LA}_{2}{ }^{+}, \mathrm{Cu}_{2} \mathrm{LA}^{+}$, $\mathrm{Cu}_{2} \mathrm{~L}^{+}$and monocopper ions as follow: $\mathrm{CuLA}_{2}{ }^{+}, \mathrm{CuLA}^{+}$, $\mathrm{CuA}_{2}{ }^{+}$, and $\mathrm{CuA}^{+}$. For both complexes the $\mathrm{Cu}_{2} \mathrm{~L}_{2}^{+\bullet}$ fragment was not detected opposite to the $\left[\mathrm{Cu}_{2}\left(\mu-\mathrm{O}_{2} \mathrm{CC}_{2} \mathrm{~F}_{5}\right)_{4}\right]$ and $\left[\mathrm{Cu}_{2}\left(\mathrm{EtNH}_{2}\right)_{2}\left(\mu-\mathrm{O}_{2} \mathrm{CC}_{2} \mathrm{~F}_{5}\right)_{4}\right]$ spectra. The formation of the $\mathrm{CuL}_{2}{ }^{+\bullet}$ ion occurred for the $\left[\mathrm{Cu}_{2}\left(s-\mathrm{BuNH}_{2}\right)_{2}\left(\mu-\mathrm{O}_{2} \mathrm{CC}_{2} \mathrm{~F}_{5}\right)_{4}\right]$ only.

The metallated ions formed by the fragmentation of the bonded ligands themselves, e.g., $\mathrm{Cu}_{2} \mathrm{~L}_{3} \mathrm{~A}\left(\mathrm{NH}_{2} \mathrm{C}_{2} \mathrm{H}_{3}\right)^{+},\left(\mathrm{Cu}_{2} \mathrm{LA}_{2}-\mathrm{CH}_{3}\right)^{+}$ filled up mass pattern (Figure 5) but in different ways for the $s e c$ - and tert-butylamine complexes. Moreover, due to the low mass resolution it is not possible to distinguish some fragments, for example the signal at $\mathrm{m} / \mathrm{z} 405$ can be the result of the formation of $\mathrm{Cu}_{2} \mathrm{LA}\left(\mathrm{CO}_{2}\right)^{+}$or $\mathrm{Cu}_{2} \mathrm{LA}\left(\mathrm{C}_{2} \mathrm{H}_{6} \mathrm{~N}\right)^{+}$fragments.

Fragments with $\mathrm{m} / \mathrm{z}$ below 140 are predominantly associated with dissociation and fragmentation of both ligand types. Carboxylate ligand fragments are less abundant for $\left[\mathrm{Cu}_{2}(t-\right.$ $\left.\left.\mathrm{BuNH}_{2}\right)_{2}\left(\mu-\mathrm{O}_{2} \mathrm{CC}_{2} \mathrm{~F}_{5}\right)_{4}\right]$. On the other hand, the fragmentation of the butylamine ligand is dominant for both molecules. For- mation of $\mathrm{A}^{+}$ion is not observed for $\left[\mathrm{Cu}_{2}\left(s-\mathrm{BuNH}_{2}\right)_{2}(\mu-\right.$ $\left.\mathrm{O}_{2} \mathrm{CC}_{2} \mathrm{~F}_{5}\right)_{4}$ ], only by stabilization via hydrogen atom detachment and formation of $(\mathrm{A}-\mathrm{H})^{+}$. Moreover, formation of fragments with $m / z 44\left(\mathrm{C}_{2} \mathrm{H}_{6} \mathrm{~N}^{+}\right.$or $\left.\mathrm{CO}_{2}{ }^{+\bullet}\right)$, and $m / z 58\left(\left(\mathrm{~A}-\mathrm{CH}_{3}\right)^{+}\right)$ is observed. The $m / z 44$ fragment is less dominant for $\left[\mathrm{Cu}_{2}(t-\right.$ $\left.\left.\mathrm{BuNH}_{2}\right)_{2}\left(\mu-\mathrm{O}_{2} \mathrm{CC}_{2} \mathrm{~F}_{5}\right)_{4}\right]$ than for the $\left[\mathrm{Cu}_{2}\left(s-\mathrm{BuNH}_{2}\right)_{2}(\mu-\right.$ $\left.\left.\mathrm{O}_{2} \mathrm{CC}_{2} \mathrm{~F}_{5}\right)_{4}\right]$ complex. For both molecules we have detected an intensive peak at $\mathrm{m} / \mathrm{z} 18$. Most probably, this is the signal relating to a water impurity as was described above for $\left[\mathrm{Cu}_{2}\left(\mu-\mathrm{O}_{2} \mathrm{CC}_{2} \mathrm{~F}_{5}\right)_{4}\right]$. However, the cation $\mathrm{NH}_{4}{ }^{+}$is registered in the pure $\mathrm{s}-\mathrm{BuNH}_{2}$ and $t-\mathrm{BuNH}_{2}$ spectra [44] so this possible ion cannot be excluded for the measured compounds at $m / z 18$.

Estimates of appearance energies of copper carboxylate complexes with alkylamine ligands have been obtained for both $\left[\mathrm{Cu}_{2}\left(\mathrm{EtNH}_{2}\right)_{2}\left(\mu-\mathrm{O}_{2} \mathrm{CC}_{2} \mathrm{~F}_{5}\right)_{4}\right]$ (Table 2) and $\left[\mathrm{Cu}_{2}\left(t-\mathrm{BuNH}_{2}\right)_{2}(\mu-\right.$ $\left.\mathrm{O}_{2} \mathrm{CC}_{2} \mathrm{~F}_{5}\right)_{4}$ ] (Table 3). However, the appearance energies were measured only for the fragments with highest intensity due to the charging effects of the monochromator electrodes relating to the measured sample. To avoid the total loss of the signal the electron current was increased which lead to decrease of the electron beam resolution and thus larger uncertainties in the determination of the appearance energies.

The present results are moreover supported by independent measurements of photoelectron spectra (PES) $[45,46]$ for two of 

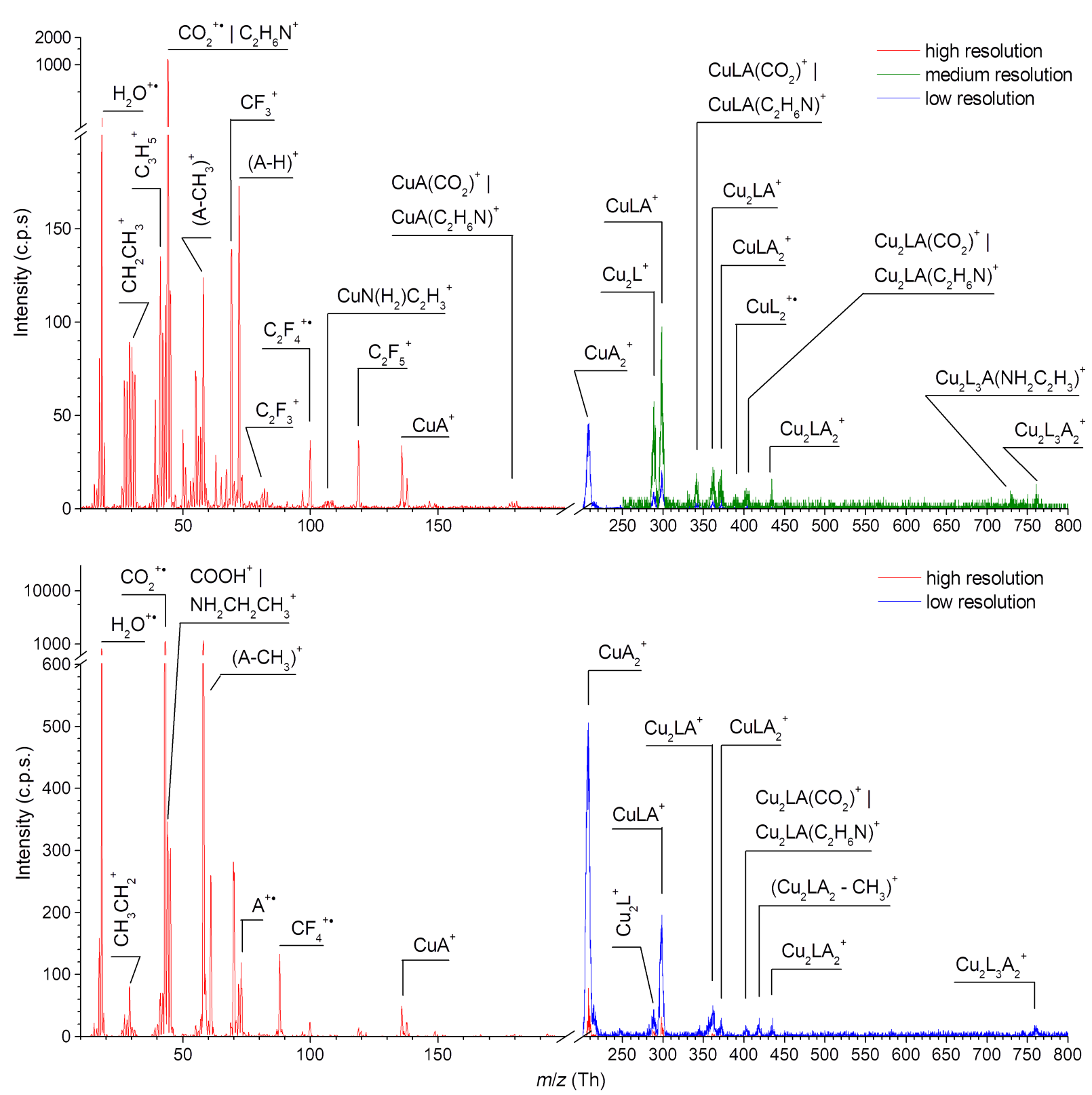

Figure 5: Mass spectrum of $\left[\mathrm{Cu}_{2}\left(s-\mathrm{BuNH}_{2}\right)_{2}\left(\mu-\mathrm{O}_{2} \mathrm{CC}_{2} \mathrm{~F}_{5}\right)_{4}\right]$ molecule (top spectrum) over the range $\mathrm{m} / \mathrm{z} 10-800$ obtained at electron energy 70 eV and mass spectrum of $\left[\mathrm{Cu}_{2}\left(t-\mathrm{BuNH}_{2}\right)_{2}\left(\mu-\mathrm{O}_{2} \mathrm{CC}_{2} \mathrm{~F}_{5}\right)_{4}\right]$ (bottom) obtained at similar conditions (temperature of the beam source of $\approx 100{ }^{\circ} \mathrm{C}$ ). For both molecules the spectral range below $\mathrm{m} / \mathrm{z} 200$ was measured with higher mass resolution (red line) but above $\mathrm{m} / \mathrm{z} 200$ (blue line) with low mass resolutions to increase the signal. For $\left[\mathrm{Cu}_{2}\left(s-\mathrm{BuNH}_{2}\right)_{2}\left(\mu-\mathrm{O}_{2} \mathrm{CC}_{2} \mathrm{~F}_{5}\right)_{4}\right]$ molecule (top spectrum) the range above $\mathrm{m} / \mathrm{z} 250$ was also measured with medium resolution (green line).

the investigated molecules, namely $\left[\mathrm{Cu}_{2}\left(\mathrm{EtNH}_{2}\right)_{2}(\mu-\right.$ $\left.\left.\mathrm{O}_{2} \mathrm{CC}_{2} \mathrm{~F}_{5}\right)_{4}\right]$ and $\left[\mathrm{Cu}_{2}\left(s-\mathrm{BuNH}_{2}\right)_{2}\left(\mu-\mathrm{O}_{2} \mathrm{CC}_{2} \mathrm{~F}_{5}\right)_{4}\right]$ (Figure 6) while PES intensities were too low for $\left[\mathrm{Cu}_{2}\left(t-\mathrm{BuNH}_{2}\right)_{2}(\mu\right.$ $\left.\left.\mathrm{O}_{2} \mathrm{CC}_{2} \mathrm{~F}_{5}\right)_{4}\right]$. The obtained data, which are similar for both molecules were interpolated using a set of six gauss functions and energies of the electronic states have been obtained from their maxima. The first electronic transition represents the value of the ionization energy. For both $\mathrm{Cu}$ alkylamine complexes the ionization energy was thus estimated to $9.3 \mathrm{eV}$.

\section{Negative ions}

Mass spectra resulting from electron attachment to all four measured compounds are shown in Figure 7 and reveal many common features. We have observed the production of the transient negative ion (TNI) $\mathrm{Cu}_{2}\left(\mathrm{O}_{2} \mathrm{CC}_{2} \mathrm{~F}_{5}\right)_{4}{ }^{-\bullet}\left(\mathrm{Cu}_{2} \mathrm{~L}_{4}{ }^{-\bullet}\right)$ only for the $\left[\mathrm{Cu}_{2}\left(\mu-\mathrm{O}_{2} \mathrm{CC}_{2} \mathrm{~F}_{5}\right)_{4}\right]$ compound. The same $\mathrm{Cu}_{2} \mathrm{~L}_{4}{ }^{-\bullet}$ ion was detected for both $\left[\mathrm{Cu}_{2}\left(\mathrm{EtNH}_{2}\right)_{2}\left(\mu-\mathrm{O}_{2} \mathrm{CC}_{2} \mathrm{~F}_{5}\right)_{4}\right]$ and $\left[\mathrm{Cu}_{2}(t\right.$ $\left.\left.\mathrm{BuNH}_{2}\right)_{2}\left(\mu-\mathrm{O}_{2} \mathrm{CC}_{2} \mathrm{~F}_{5}\right)_{4}\right]$ complexes, but with relatively lower ion yields and in this case is the DEA product already and not 
Table 2: Appearance energies for selected ions from dissociation of $\left[\mathrm{Cu}_{2}\left(\mathrm{EtNH}_{2}\right)_{2}\left(\mu-\mathrm{O}_{2} \mathrm{CC}_{2} \mathrm{~F}_{5}\right)_{4}\right]$ induced by electron impact ionization.

\begin{tabular}{lll}
$m / z$ & Ion & $A E^{1}[\mathrm{eV}]$ \\
\hline 18 & $\mathrm{H}_{2} \mathrm{O}^{+\bullet} / \mathrm{NH}_{4}{ }^{+}$ & $12.9^{\mathrm{a}}$ \\
30 & $\mathrm{C}_{2} \mathrm{H}_{6}{ }^{+\bullet} / \mathrm{CH}_{2} \mathrm{NH}_{2}^{+}$ & $10.3^{\mathrm{a}}$ \\
44 & $\mathrm{C}_{2} \mathrm{H}_{6} \mathrm{~N}^{+} / \mathrm{CO}_{2}^{+\cdot}$ & $11.4^{\mathrm{a}}$ \\
45 & $\mathrm{EtNH}_{2}^{+\bullet}$ & $9.0^{\mathrm{a}}$ \\
69 & $\mathrm{CF}_{3}^{+}$ & $14.1^{\mathrm{b}}$ \\
189 & $\mathrm{Cu}_{3}^{+}$ & $24.5^{\mathrm{d}}$ \\
270 & $\mathrm{CuLA}^{+}$ & $14.6^{\mathrm{a}}$ \\
288 & $\mathrm{Cu}_{2} \mathrm{~L}^{+}$ & $12.8^{\mathrm{a}}$ \\
316 & $\mathrm{CuLA}_{2}^{+}$ & $12.9^{\mathrm{a}}$ \\
334 & $\mathrm{Cu}_{2} \mathrm{LA}^{+}$ & $15.1^{\mathrm{b}}$ \\
704 & $\mathrm{Cu}_{2} \mathrm{~L}_{3} \mathrm{~A}_{2}^{+}$ & $11.8^{\mathrm{c}}$ \\
\hline
\end{tabular}

a Uncertainty $\pm 0.5 \mathrm{eV},{ }^{b}$ uncertainty $\pm 1 \mathrm{eV},{ }^{c}$ uncertainty $\pm 2 \mathrm{eV}$, duncertainty $\pm 4 \mathrm{eV}$.

Table 3: Appearance energies for selected ions from dissociation of $\left[\mathrm{Cu}_{2}\left(t-\mathrm{BuNH}_{2}\right)_{2}\left(\mu-\mathrm{O}_{2} \mathrm{CC}_{2} \mathrm{~F}_{5}\right)_{4}\right]$ induced by electron impact ionization.

\begin{tabular}{llll}
$m / z$ & lon & $A E^{1}[\mathrm{eV}]$ & $A E^{2}[\mathrm{eV}]$ \\
\hline 58 & $\left(\mathrm{~A}-\mathrm{CH}_{3}\right)^{+}$ & $9.1^{\mathrm{a}}$ & \\
119 & $\mathrm{C}_{2} \mathrm{~F}_{5}{ }^{+}$ & $10.2^{\mathrm{a}}$ & $15.7^{\mathrm{a}}$ \\
136 & $\mathrm{CuA}^{+}$ & $17.0^{\mathrm{b}}$ & \\
193 & $\mathrm{Cut}^{-} \mathrm{Bu}_{2} \mathrm{NH}_{2}{ }^{+}$ & $15.2^{\mathrm{a}}$ & \\
208 & $\mathrm{CuA}_{2}{ }^{+}$ & $11.1^{\mathrm{a}}$ & $15.9^{\mathrm{a}}$ \\
298 & $\mathrm{CuLA}^{+}$ & $13.5^{\mathrm{b}}$ & \\
\hline
\end{tabular}

auncertainty $\pm 0.5 \mathrm{eV},{ }^{\mathrm{b}}$ uncertainty $\pm 1 \mathrm{eV}$.

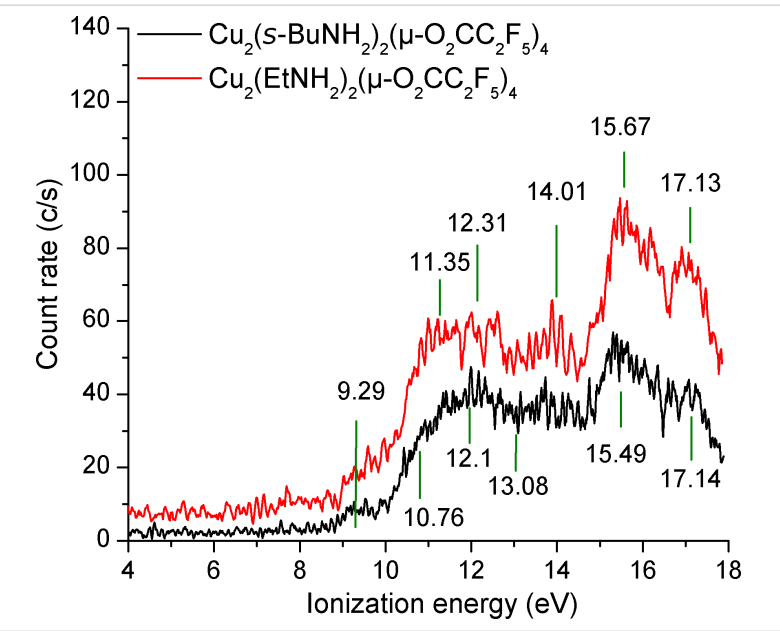

Figure 6: Photoelectron spectra of copper(II) carboxylate complexes $\left[\mathrm{Cu}_{2}\left(\mathrm{EtNH}_{2}\right)_{2}\left(\mu-\mathrm{O}_{2} \mathrm{CC}_{2} \mathrm{~F}_{5}\right)_{4}\right]$ (red line/upper) and $\left[\mathrm{Cu}_{2}\left(s-\mathrm{BuNH}_{2}\right)_{2}(\mu-\right.$ $\left.\mathrm{O}_{2} \mathrm{CC}_{2} \mathrm{~F}_{5}\right)_{4}$ ] (black line/bottom).

TNI. The exception was $\left[\mathrm{Cu}_{2}\left(s-\mathrm{BuNH}_{2}\right)_{2}\left(\mu-\mathrm{O}_{2} \mathrm{CC}_{2} \mathrm{~F}_{5}\right)_{4}\right]$, which has the weakest ion yield signal from DEA. Furthermore, DEA leads to production of $\mathrm{CuL}_{3}{ }^{-}$and $\mathrm{CuL}_{2}{ }^{-}$ions while a weak signal due to $\mathrm{CuL}^{-\cdot}$ was detected only for $\left[\mathrm{Cu}_{2}\left(\mu-\mathrm{O}_{2} \mathrm{CC}_{2} \mathrm{~F}_{5}\right)_{4}\right]$. A common feature of DEA to all four measured compounds is that the only dinuclear ionic structure was detected for $\mathrm{Cu}_{2} \mathrm{~L}_{4}{ }^{-\bullet}$; all the other fragments produced via loss of ligand(s) are associated with one $\mathrm{Cu}$ atom only, the dinuclear structure is thus broken.

In addition to copper-containing fragments, the dissociated carboxylate ligand $\mathrm{O}_{2} \mathrm{CC}_{2} \mathrm{~F}_{5}{ }^{-}$was detected. Despite the fact that this structure represents a close shell system, the open shell $\mathrm{O}_{2} \mathrm{CC}_{2} \mathrm{~F}_{4}{ }^{-\bullet}$ ion is generally more intense. Moreover, the latter ion can be converted to the $\mathrm{C}_{2} \mathrm{~F}_{4}{ }^{-\bullet}$ radical anion by loss of carbon dioxide.

Relative DEA cross sections of different negative ions $\left(\mathrm{Cu}_{2} \mathrm{~L}_{4}{ }^{-\bullet}, \mathrm{CuL}_{3}{ }^{-}, \mathrm{CuL}_{2}^{-}, \mathrm{L}^{-}, \mathrm{O}_{2} \mathrm{CC}_{2} \mathrm{~F}_{4}{ }^{-\bullet}\right.$ and $\left.\mathrm{C}_{2} \mathrm{~F}_{4}{ }^{-\bullet}\right)$ formed from each of the discussed copper carboxylate complexes were recorded (Figure 8) except for $\left[\mathrm{Cu}_{2}\left(s-\mathrm{BuNH}_{2}\right)_{2}\left(\mu-\mathrm{O}_{2} \mathrm{CC}_{2} \mathrm{~F}_{5}\right)_{4}\right]$ where the signal was insufficient. A strong feature of a single particle resonance close to $0 \mathrm{eV}$ is seen for all DEA products. This is in fact possible only when the electron affinities (EA) of the individual products are large enough to compensate the corresponding bond dissociation energies (BDE) [47]. However, we have no quantitative information about the EA and BDE of the individual products shown in Figure 8. The position of the resonance is slightly shifted towards $1 \mathrm{eV}$ with decreasing the $\mathrm{m} / \mathrm{z}$ of the final negative ionic product. This shift is quite obvious for the formation of the $\mathrm{C}_{2} \mathrm{~F}_{4}{ }^{-\bullet}$ ion as well as for the formation of the $\mathrm{Cu}\left(\mathrm{O}_{2} \mathrm{CC}_{2} \mathrm{~F}_{5}\right)_{2}{ }^{-}$ion from the $\left[\mathrm{Cu}_{2}\left(\mathrm{EtNH}_{2}\right)_{2}(\mu\right.$ $\left.\left.\mathrm{O}_{2} \mathrm{CC}_{2} \mathrm{~F}_{5}\right)_{4}\right]$ molecule.

\section{Discussion \\ Positive ions}

The dissociation pattern of dissociative ionization of the investigated molecules showed loss of entire ligands as well as fragments containing only copper atom (Figure 9). Limited numbers of fragments containing more than two carboxylate ligands are observed $\left(\mathrm{Cu}_{2} \mathrm{~L}_{4}^{+}, \mathrm{Cu}_{2} \mathrm{~L}_{3}{ }^{+}, \mathrm{Cu}_{2} \mathrm{~L}_{3} \mathrm{~A}_{2}{ }^{+}\right)$. However, it is important to note that intensity of fragments with higher masses is discriminated during their transition through the ion optics and quadrupole system of the experiment.

For $\left[\mathrm{Cu}_{2}\left(\mathrm{RNH}_{2}\right)_{2}\left(\mu-\mathrm{O}_{2} \mathrm{CC}_{2} \mathrm{~F}_{5}\right)_{4}\right](\mathrm{R}=\mathrm{Et}, s$-Bu, $t$ - $\mathrm{Bu})$ complexes, the largest detected fragment contained three carboxylate ligands, $\mathrm{Cu}_{2} \mathrm{~L}_{3} \mathrm{~A}_{2}{ }^{+}$. Moreover, the ions $\mathrm{Cu}_{2} \mathrm{~L}_{3} \mathrm{~A}^{+}$and $\mathrm{Cu}_{2} \mathrm{~L}_{3} \mathrm{~A}\left(\mathrm{NH}_{2} \mathrm{C}_{2} \mathrm{H}_{3}\right)^{+}$were formed for $\mathrm{R}=\mathrm{Et}$ or $s-\mathrm{Bu}$, respectively. The presence of the following fragments: $\mathrm{Cu}_{2} \mathrm{~L}^{+}, \mathrm{CuA}_{2}^{+}$, $\mathrm{CuA}^{+}$confirms that the copper oxidation state is reduced from two to one. For all three amine complexes similar cationic products containing one or no carboxylate ligand $\left(\mathrm{Cu}_{2} \mathrm{~L}_{\mathrm{x}} \mathrm{A}_{\mathrm{y}}{ }^{+}\right.$and $\mathrm{CuL}_{\mathrm{x}} \mathrm{A}_{\mathrm{y}}{ }^{+}$, where $\left.\mathrm{x}=0,1 ; \mathrm{y}=1,2\right)$ can be observed. Moreover, 


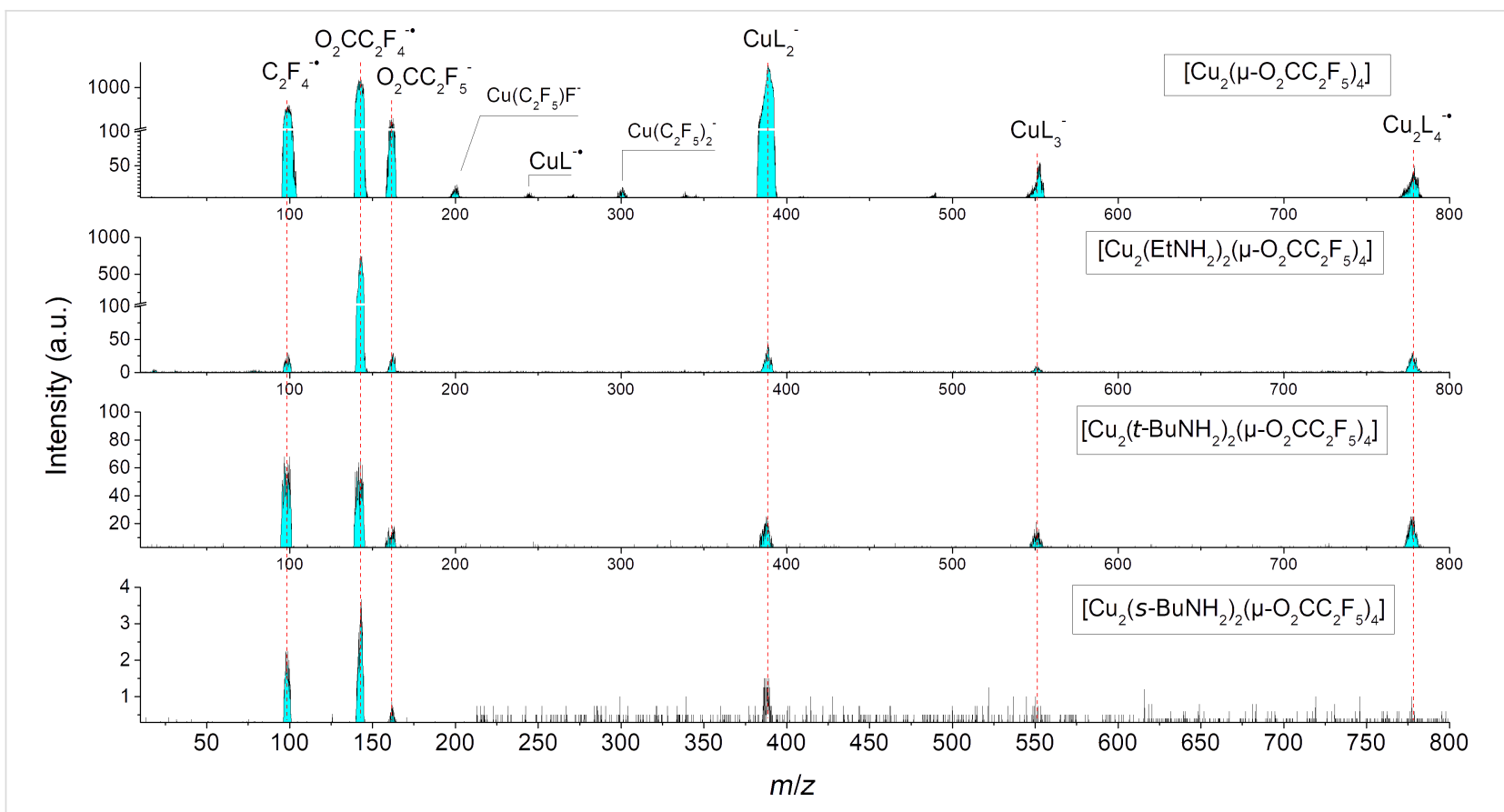

Figure 7: Negative ions mass spectra of copper carboxylate molecules. The spectra were obtained at the energy where maximal ion count of $\mathrm{SF}_{6}{ }^{-}$ ion production from $\mathrm{SF}_{6}$ is observed, which is close to $0 \mathrm{eV}$.

for the $\left[\mathrm{Cu}_{2}\left(\mathrm{EtNH}_{2}\right)_{2}\left(\mu-\mathrm{O}_{2} \mathrm{CC}_{2} \mathrm{~F}_{5}\right)_{4}\right]$ amine complex, the production of $\mathrm{Cu}^{+}$atomic ion is visible, but negligible in contrast to the $\left[\mathrm{Cu}_{2}\left(\mu-\mathrm{O}_{2} \mathrm{CC}_{2} \mathrm{~F}_{5}\right)_{4}\right]$ molecule. The formation of the $\mathrm{Cu}_{2}{ }^{+}$ ion was not observed as well.

Appearance energies could be measured for almost thirty different fragments of the studied molecules, (excluding $\left[\mathrm{Cu}_{2}(s-\right.$ $\left.\left.\left.\mathrm{BuNH}_{2}\right)_{2}\left(\mu-\mathrm{O}_{2} \mathrm{CC}_{2} \mathrm{~F}_{5}\right)_{4}\right]\right)$, but not for the intact complex. As ionization energies were thus not obtained for any of the measured molecules by the electron-molecular beam experiment, PES were acquired for $\left[\mathrm{Cu}_{2}\left(\mathrm{EtNH}_{2}\right)_{2}\left(\mu-\mathrm{O}_{2} \mathrm{CC}_{2} \mathrm{~F}_{5}\right)_{4}\right]$ and $\left[\mathrm{Cu}_{2}\left(s-\mathrm{BuNH}_{2}\right)_{2}\left(\mu-\mathrm{O}_{2} \mathrm{CC}_{2} \mathrm{~F}_{5}\right)_{4}\right]$ yielding ionization energies of $I E=9.3 \mathrm{eV}$. Based on the very similar structure, a similar $I E$ is expected for $\left[\mathrm{Cu}_{2}\left(t-\mathrm{BuNH}_{2}\right)_{2}\left(\mu-\mathrm{O}_{2} \mathrm{CC}_{2} \mathrm{~F}_{5}\right)_{4}\right]$ while the ionization energy of $\left[\mathrm{Cu}_{2}\left(\mu-\mathrm{O}_{2} \mathrm{CC}_{2} \mathrm{~F}_{5}\right)_{4}\right]$ may be markedly different due to the absence of alkylamine ligands.

As shown in Figure 3 and listed in Table 1, we have obtained for $\left[\mathrm{Cu}_{2}\left(\mu-\mathrm{O}_{2} \mathrm{CC}_{2} \mathrm{~F}_{5}\right)_{4}\right]$ appearance energies for sequential loss of carboxylate ligands. Usually, the dissociation of ligands from coordination compounds requires higher incident electron energies with increasing number of ligands dissociated from the complex [17-19]. However, here the loss of two carboxylate ligands is energetically the lowest with $A E_{452}=9.7 \mathrm{eV}$. Dissociation of first and third carboxylate ligands occur with similar values of $A E_{615}=11.4 \mathrm{eV}$ and $A E_{289}=11.9 \mathrm{eV}$, respectively. Thus dissociation does not follow a simple one by one ligand loss mechanism. The similar values of $A E_{615}$ and $A E_{289}$ may be explained only in the case, that while the formation of $\mathrm{Cu}_{2}\left(\mathrm{O}_{2} \mathrm{CC}_{2} \mathrm{~F}_{5}\right)_{3}{ }^{+}$ion occur as a dissociation process from the parent cation, the second threshold at $15.2 \mathrm{eV}$ for formation of $\mathrm{Cu}_{2}\left(\mathrm{O}_{2} \mathrm{CC}_{2} \mathrm{~F}_{5}\right)_{2}{ }^{+}$would represent the spontaneous dissociation of the carboxylate ligand from the $\mathrm{Cu}_{2}\left(\mathrm{O}_{2} \mathrm{CC}_{2} \mathrm{~F}_{5}\right)_{3}{ }^{+}$ion. The formation of $\mathrm{Cu}_{2}\left(\mathrm{O}_{2} \mathrm{CC}_{2} \mathrm{~F}_{5}\right)^{+}$is a result of ligand loss from $\mathrm{Cu}_{2}\left(\mathrm{O}_{2} \mathrm{CC}_{2} \mathrm{~F}_{5}\right)_{2}{ }^{+\bullet}$. We can thus estimate the bond dissociation energy (as the difference of appearance energies of the corresponding ions) $B D E\left[\mathrm{Cu}_{2}\left(\mathrm{O}_{2} \mathrm{CC}_{2} \mathrm{~F}_{5}\right)_{2}^{+\bullet}-\left(\mathrm{O}_{2} \mathrm{CC}_{2} \mathrm{~F}_{5}\right)\right]=A E_{452}-$ $A E_{615}=3.8 \mathrm{eV}, B D E\left[\mathrm{Cu}_{2}\left(\mathrm{O}_{2} \mathrm{CC}_{2} \mathrm{~F}_{5}\right)^{+}-\left(\mathrm{O}_{2} \mathrm{CC}_{2} \mathrm{~F}_{5}\right)\right]=A E_{289}-$ $A E_{452}=2.3 \mathrm{eV}$.

The measured appearance energies of $\mathrm{CuLA}_{2}{ }^{+}$ $\left(A E_{316}=12.9 \mathrm{eV}\right)$ and $\mathrm{CuLA}^{+}\left(A E_{270}=14.6 \mathrm{eV}\right)$ produced from $\left[\mathrm{Cu}_{2}\left(\mathrm{EtNH}_{2}\right)_{2}\left(\mu-\mathrm{O}_{2} \mathrm{CC}_{2} \mathrm{~F}_{5}\right)_{4}\right]$ show that $B D E$ $\left[\mathrm{Cu}\left(\mathrm{EtNH}_{2}\right)\left(\mathrm{O}_{2} \mathrm{CC}_{2} \mathrm{~F}_{5}\right)^{+}-\mathrm{EtNH}_{2}\right] \approx 1.7 \mathrm{eV}$. On the other hand the comparison of $A E \mathrm{~s}$ of the $\mathrm{CuLA}^{+}$with its dinuclear counterpart $\mathrm{Cu}_{2} \mathrm{LA}^{+}$prefers in energy the formation of the smaller fragment $\mathrm{CuLA}^{+}\left(A E_{270}=14.6 \mathrm{eV}\right)$ contrary to $\mathrm{Cu}_{2} \mathrm{LA}^{+}$ $\left(A E_{334}=15.1 \mathrm{eV}\right)$.

The dissociation pattern of the carboxylate ligand is visible well for the $\left[\mathrm{Cu}_{2}\left(\mu-\mathrm{O}_{2} \mathrm{CC}_{2} \mathrm{~F}_{5}\right)_{4}\right]$ molecule. Its fragmentation can be compared with the dissociation pattern of a similar molecule, the pentafluoropropionic acid $\mathrm{C}_{2} \mathrm{~F}_{5} \mathrm{COOH}$ [48]. Similarly as for the $\mathrm{C}_{2} \mathrm{~F}_{5} \mathrm{COOH}$ we have seen formation of $\mathrm{C}_{2} \mathrm{~F}_{5}{ }^{+}$with $\mathrm{m} / z 119$, $\mathrm{C}_{2} \mathrm{~F}_{4}{ }^{+\bullet}$ with $m / z 100, \mathrm{CF}_{3}{ }^{+}$with $m / z 69$ or $\mathrm{CF}^{+}$with $m / z 31$. We can clearly observe that the $\mathrm{C}_{2} \mathrm{~F}_{5}{ }^{+}$formation $\left(A E_{119}=15.1 \mathrm{eV}\right)$ 


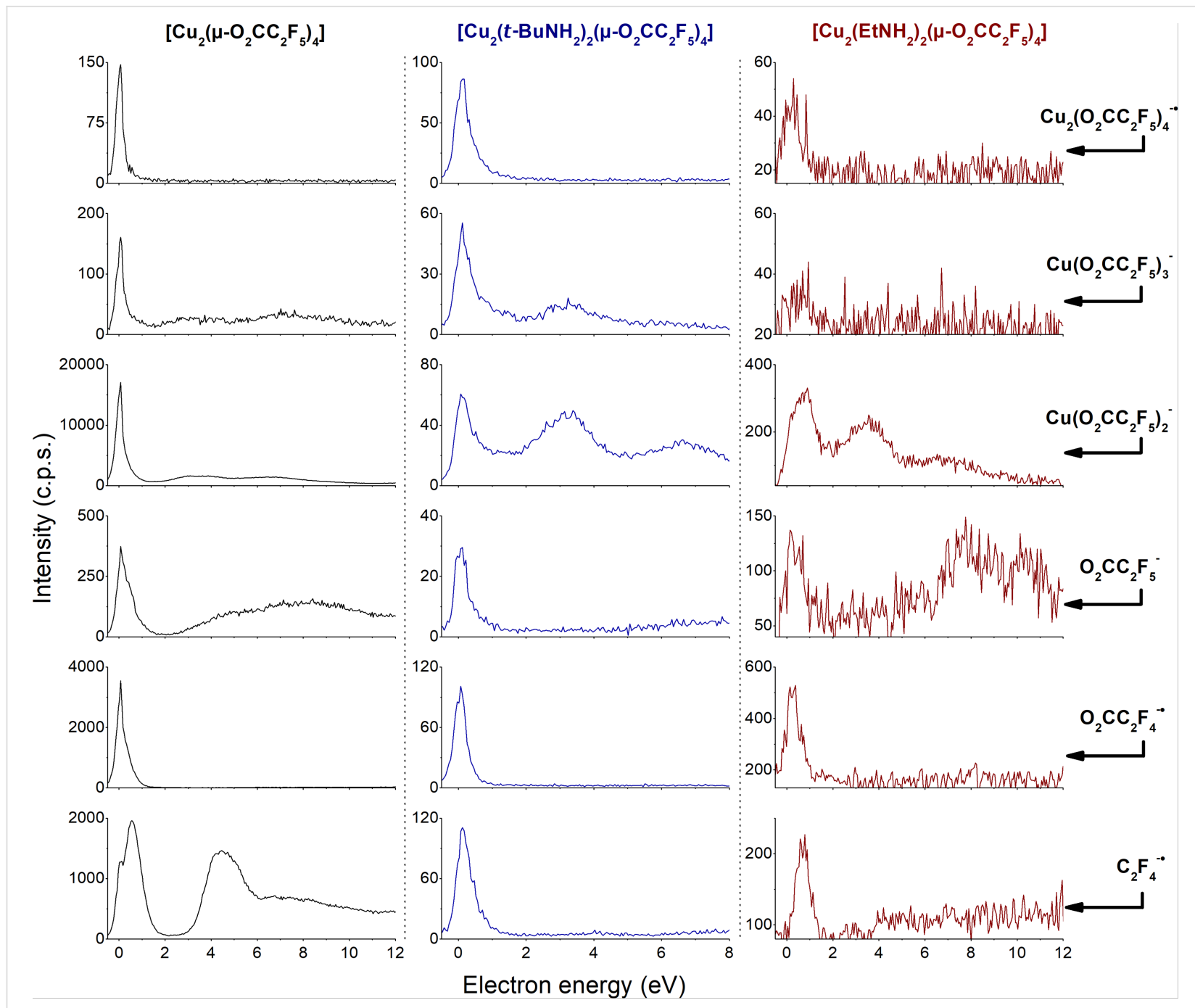

Figure 8: Relative ion yields of negative products from $\left[\mathrm{Cu}_{2}\left(\mu-\mathrm{O}_{2} \mathrm{CC}_{2} \mathrm{~F}_{5}\right)_{4}\right]$ (left column), $\left[\mathrm{Cu}_{2}\left(t-\mathrm{BuNH}_{2}\right)_{2}\left(\mu-\mathrm{O}_{2} \mathrm{CC}_{2} \mathrm{~F}_{5}\right)_{4}\right]($ middle column) and $\left[\mathrm{Cu}_{2}\left(\mathrm{EtNH}_{2}\right)_{2}\left(\mu-\mathrm{O}_{2} \mathrm{CC}_{2} \mathrm{~F}_{5}\right)_{4}\right]$ (right column) as function of electron energy. Each row represents the negative ion shown on the right. The energy scale was calibrated with respect to the formation of $\mathrm{SF}_{6}{ }^{-}$by electron attachment to $\mathrm{SF}_{6}$ that occurs at an electron energy $\approx 0 \mathrm{eV}$.

requires more energy than dissociation of one additional fluorine atom to form the $\mathrm{C}_{2} \mathrm{~F}_{4}{ }^{+\bullet}$ ion $\left(A E_{100}=12.2 \mathrm{eV}\right)$. The dissociation of a fluorine atom can lead to a $\mathrm{C}=\mathrm{C}$ double bond in $\mathrm{C}_{2} \mathrm{~F}_{4}{ }^{+}$which in fact compensates the energy needed for the dissociation of the $\mathrm{C}-\mathrm{F}$ bond and can be observed as a energy decrease of $A E_{100}$ in comparison to $A E_{119}$. The formation of $\mathrm{CF}_{3}{ }^{+}$ion with $\mathrm{m} / z 69$ is detected with two thresholds at $A E^{1}{ }_{69}=11.7 \mathrm{eV}$ and $A E^{2}{ }_{69}=16.1 \mathrm{eV}$. Loss of one more fluorine atom leads to $\mathrm{CF}_{2}{ }^{+}(\mathrm{m} / \mathrm{z} 50)$ with $A E_{50}=14.4 \mathrm{eV}$. The formation of $\mathrm{CF}^{+}$ion with $\mathrm{m} / \mathrm{z} 31$ is again detected with two thresholds at $A E^{1}{ }_{31}=11.0 \mathrm{eV}$ and $A E^{2}{ }_{31}=18.4 \mathrm{eV}$. The first threshold occurs at the energy, which is below the dissociation limit for $\mathrm{CF}_{3}$ as well as $\mathrm{CF}_{2}$ ions. From the dissociation sequence we can estimate the bond dissociation energy of the fluorine atom in the present $\mathrm{CF}_{3}{ }^{+}$ion as: $B D E\left[\mathrm{CF}_{2}{ }^{+}-\mathrm{F}\right]=2.7 \mathrm{eV}$ and $B D E\left[\mathrm{CF}^{+}-\mathrm{F}\right]=4.0 \mathrm{eV}$. For com- parison, the same energies for the $\mathrm{CF}_{4}$ molecule after EI are $B D E\left[\mathrm{CF}_{2}{ }^{+}-\mathrm{F}\right] \approx 6 \mathrm{eV}$ and $B D E\left[\mathrm{CF}^{+}-\mathrm{F}\right]=2.3 \mathrm{eV}[49,50]$. An additional comparison may be provided with hexafluoroethane $\left(\mathrm{C}_{2} \mathrm{~F}_{6}\right)$ [51], where the appearance energy difference between $\mathrm{CF}_{3}{ }^{+}$and $\mathrm{CF}^{+}$ion is $\approx 3 \mathrm{eV}$ in relation to almost $7 \mathrm{eV}$ difference for the $\left[\mathrm{Cu}_{2}\left(\mu-\mathrm{O}_{2} \mathrm{CC}_{2} \mathrm{~F}_{5}\right)_{4}\right]$ compound. Moreover, the formation of the $\mathrm{C}_{2} \mathrm{~F}_{4}{ }^{+\bullet}$ ion requires $5.7 \mathrm{eV}$ more than formation of $\mathrm{C}_{2} \mathrm{~F}_{5}{ }^{+}$ion from hexafluoroethane. We detected an opposite trend with the difference of slightly over $3 \mathrm{eV}$. This significant effect is provided by the presence of the carboxyl group.

For all three studied complexes, the fragmentation of the alkylamine ligand cation is observed with higher intensity than that of the carboxylate ligand. For $\left[\mathrm{Cu}_{2}\left(\mathrm{EtNH}_{2}\right)_{2}\left(\mu-\mathrm{O}_{2} \mathrm{CC}_{2} \mathrm{~F}_{5}\right)_{4}\right]$ and $\left[\mathrm{Cu}_{2}\left(s-\mathrm{BuNH}_{2}\right)_{2}\left(\mu-\mathrm{O}_{2} \mathrm{CC}_{2} \mathrm{~F}_{5}\right)_{4}\right]$, it is produced as a deprotonated $(\mathrm{A}-\mathrm{H})^{+}$ion instead of $\mathrm{A}^{+}$, visible in the spectrum of 

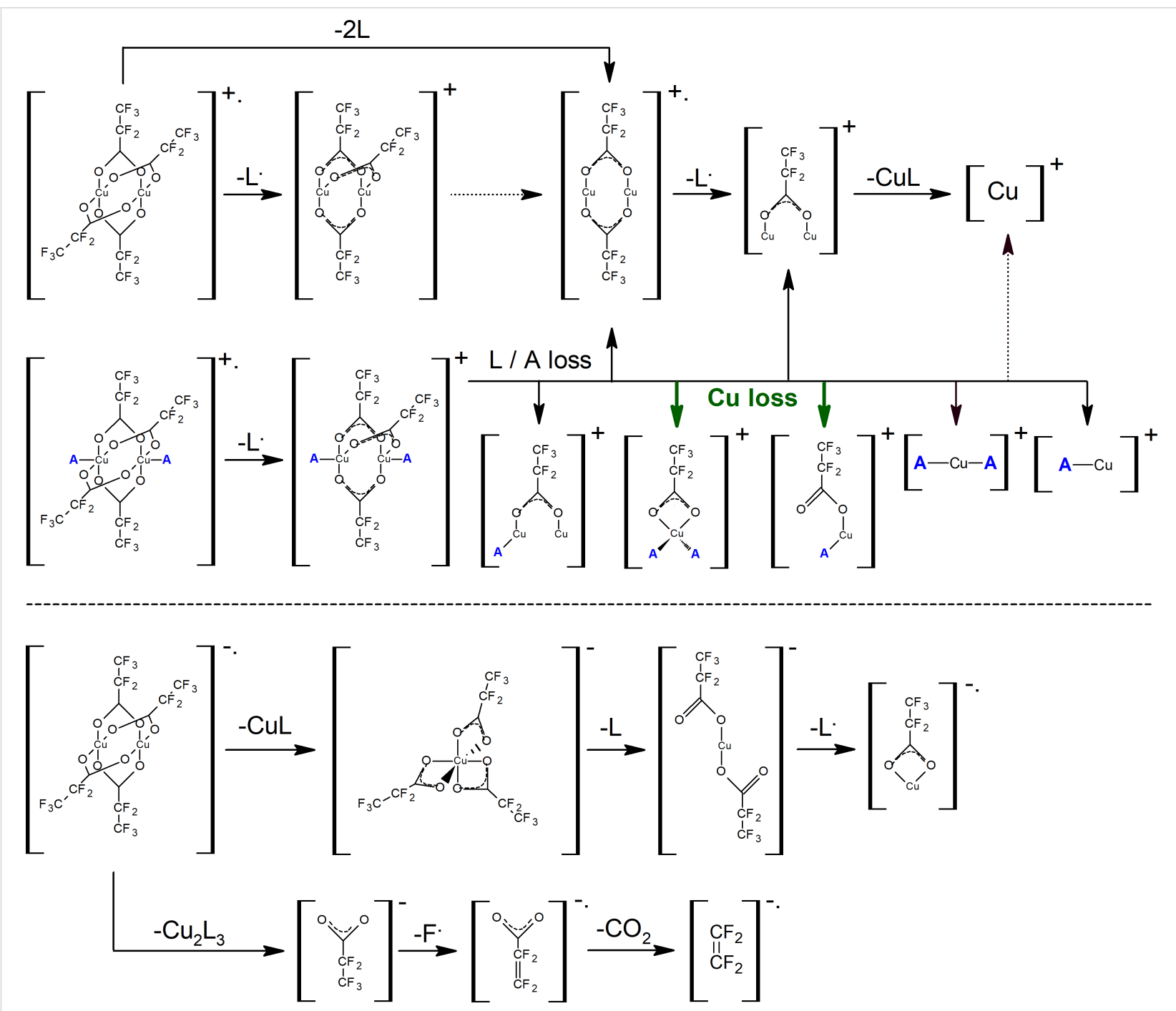

Figure 9: Summary and visualization of the most important ion formation pathways for DI (top) and DEA (bottom).

$\left[\mathrm{Cu}_{2}\left(t-\mathrm{BuNH}_{2}\right)_{2}\left(\mu-\mathrm{O}_{2} \mathrm{CC}_{2} \mathrm{~F}_{5}\right)_{4}\right]$. In the case of $\left[\mathrm{Cu}_{2}\left(\mathrm{EtNH}_{2}\right)_{2}(\mu-\right.$ $\left.\mathrm{O}_{2} \mathrm{CC}_{2} \mathrm{~F}_{5}\right)_{4}$ ], the fragmentation leads only to the formation of a fragment with $\mathrm{m} / \mathrm{z} 30$ as assigned to $\mathrm{C}_{2} \mathrm{H}_{6}{ }^{+\bullet}$ or more probable to $\mathrm{H}_{2} \mathrm{NCH}_{2}{ }^{+}$. The registered spectrum is the superposition of the thermal loss $\mathrm{EtNH}_{2}$ and the complex spectra what influenced the observed signals intensities. Mass spectra for sec-butylamine and tert-butylamine show one dominant dissociation product: $\mathrm{H}_{2} \mathrm{NC}(\mathrm{H}) \mathrm{CH}_{3}{ }^{+}$with $\mathrm{m} / z 44$ and $\mathrm{H}_{2} \mathrm{NC}\left(\mathrm{CH}_{3}\right)_{2}{ }^{+}$with $m / z 58$, respectively [44]. Both of these processes are also observed in corresponding dissociation patterns of the molecules investigated here. The ion with $m / z 44$ may also be associated with $\mathrm{CO}_{2}{ }^{+\bullet}$. However, the appearance energy of $\mathrm{m} / \mathrm{z} 44$ from $\left[\mathrm{Cu}_{2}\left(\mathrm{EtNH}_{2}\right)_{2}\left(\mu-\mathrm{O}_{2} \mathrm{CC}_{2} \mathrm{~F}_{5}\right)_{4}\right]$ is lower than that of $\mathrm{CO}_{2}^{+\bullet}$ from $\mathrm{CO}_{2}[52]$. This points to an assignment to $(\mathrm{A}-\mathrm{H})^{+}$as may also be expected for the s-BuNH${ }_{2}$ and $t-\mathrm{BuNH}_{2}$ complexes. Moreover, the $A E$ detected for $\mathrm{H}_{2} \mathrm{NC}\left(\mathrm{CH}_{3}\right)_{2}{ }^{+}\left(\mathrm{m} / z\right.$ 58) from $\left[\mathrm{Cu}_{2}(t-\right.$ $\left.\left.\mathrm{BuNH}_{2}\right)_{2}\left(\mu-\mathrm{O}_{2} \mathrm{CC}_{2} \mathrm{~F}_{5}\right)_{4}\right]$ of $A E_{58}=9.1 \mathrm{eV}$ is similar to the PES value of its $I E=9.3 \mathrm{eV}$. We can thus conclude that the dissociation of the amine ligand from the complex and the consequential dissociation of one methyl group as well as the second methyl group are extremely effective processes. For $\left[\mathrm{Cu}_{2}(s-\right.$ $\left.\left.\mathrm{BuNH}_{2}\right)_{2}\left(\mu-\mathrm{O}_{2} \mathrm{CC}_{2} \mathrm{~F}_{5}\right)_{4}\right]$, the loss of an ethyl group is a dominant product of alkylamine ligand fragmentation. Additionally, the single methyl group dissociation is observed. Other remaining fragments of the studied molecules relate to additional hydrogen or carbon dissociations.

\section{Negative ions}

In the fragmentation pattern obtained via DEA, we observed with particularly high intensity the symmetrical splitting of the $\mathrm{Cu}_{2}\left(\mathrm{O}_{2} \mathrm{CC}_{2} \mathrm{~F}_{5}\right)_{4}^{-\cdot}$ ion into the $\mathrm{Cu}\left(\mathrm{O}_{2} \mathrm{CC}_{2} \mathrm{~F}_{5}\right)_{2}^{-}$and $\mathrm{Cu}\left(\mathrm{O}_{2} \mathrm{CC}_{2} \mathrm{~F}_{5}\right)_{2}$ fragments. Therefore, we can suppose that the lowest unoccupied molecular orbital (LUMO) of the measured complexes has an antibonding character and consists from 
$\mathrm{d}$-orbitals on $\mathrm{Cu}$ atoms, and $\mathrm{p}$-orbitals from the corresponding $\mathrm{O}$ atoms. However, Figure 7 shows a difference in the relative intensity of $\mathrm{Cu}\left(\mathrm{O}_{2} \mathrm{CC}_{2} \mathrm{~F}_{5}\right)_{2}{ }^{-}$ion formed via DEA for all four compounds. While it is the most intensive product for the $\left[\mathrm{Cu}_{2}\left(\mathrm{O}_{2} \mathrm{CC}_{2} \mathrm{~F}_{5}\right)_{4}\right]$ measured at electron energy close to $0 \mathrm{eV}$, its intensity is significantly lower in the spectra of the other three complexes, measured at the same electron energy. The maximum of this DEA channel in the $\left[\mathrm{Cu}_{2}\left(\mathrm{RNH}_{2}\right)_{2}(\mu\right.$ $\left.\mathrm{O}_{2} \mathrm{CC}_{2} \mathrm{~F}_{5}\right)_{4}$ ] compounds is shifted towards higher energies (Figure 8), which in fact is a consequence of more bonds to be dissociated to produce the same product $\mathrm{Cu}\left(\mathrm{O}_{2} \mathrm{CC}_{2} \mathrm{~F}_{5}\right)_{2}{ }^{-}$. Moreover, the $\mathrm{Cu}-\mathrm{N}$ bond is involved in the DEA, as well as one of the $\mathrm{Cu}-\mathrm{O}$ bonds of each $\mathrm{Cu}$-carboxyl part of the complex. Thus, DEA to the all complexes leading to $\mathrm{Cu}_{2}\left(\mathrm{O}_{2} \mathrm{CC}_{2} \mathrm{~F}_{5}\right)_{4}{ }^{-\bullet}$ was observed. At the same point if it is the antibonding character of $\mathrm{Cu}-\mathrm{O}$ bonds and interactions between copper ions then it gives rise to ionic products $\mathrm{Cu}\left(\mathrm{O}_{2} \mathrm{CC}_{2} \mathrm{~F}_{5}\right)_{3}{ }^{-}, \mathrm{Cu}\left(\mathrm{O}_{2} \mathrm{CC}_{2} \mathrm{~F}_{5}\right)_{2}{ }^{-}$, and $\mathrm{Cu}\left(\mathrm{O}_{2} \mathrm{CC}_{2} \mathrm{~F}_{5}\right)^{-\bullet}$. The ion yield for these reactions peaks close to $0 \mathrm{eV}$. Fragmentations with additional ligand dissociation processes have been observed, forming still well visible peaks with $m / z \approx 201$ and $m / z \approx 301$. The signals can be assigned to $\mathrm{Cu}\left(\mathrm{C}_{2} \mathrm{~F}_{5}\right) \mathrm{F}^{-}$for the peak with $m / z \approx 201$ and $\mathrm{Cu}\left(\mathrm{C}_{2} \mathrm{~F}_{5}\right)_{2}{ }^{-}$for the peak with $m / z \approx 301$. For $\left[\mathrm{Cu}_{2}\left(\mu-\mathrm{O}_{2} \mathrm{CC}_{2} \mathrm{~F}_{5}\right)_{4}\right]$, the dissociation through higher energy resonances leads only to smaller fragments (Figure 8). $\left[\mathrm{Cu}_{2}\left(\mathrm{EtNH}_{2}\right)_{2}\left(\mu-\mathrm{O}_{2} \mathrm{CC}_{2} \mathrm{~F}_{5}\right)_{4}\right]$ and $\left[\mathrm{Cu}_{2}(t\right.$ $\left.\left.\mathrm{BuNH}_{2}\right)_{2}\left(\mu-\mathrm{O}_{2} \mathrm{CC}_{2} \mathrm{~F}_{5}\right)_{4}\right]$, similar to $\left[\mathrm{Cu}_{2}\left(\mu-\mathrm{O}_{2} \mathrm{CC}_{2} \mathrm{~F}_{5}\right)_{4}\right]$, are characterized by the same DEA products. Moreover, new energetic channels leading to $\mathrm{Cu}\left(\mathrm{O}_{2} \mathrm{CC}_{2} \mathrm{~F}_{5}\right)_{2}{ }^{-}$areas appear at $3.6 \mathrm{eV}$ and $6.4 \mathrm{eV}$ for $\left[\mathrm{Cu}_{2}\left(t-\mathrm{BuNH}_{2}\right)_{2}\left(\mu-\mathrm{O}_{2} \mathrm{CC}_{2} \mathrm{~F}_{5}\right)_{4}\right]$ and at $3.7 \mathrm{eV}$ and $7 \mathrm{eV}$ for $\left[\mathrm{Cu}_{2}\left(\mathrm{EtNH}_{2}\right)_{2}\left(\mu-\mathrm{O}_{2} \mathrm{CC}_{2} \mathrm{~F}_{5}\right)_{4}\right]$. The experimental results show that DEA to these complexes will also lead to formation of the ligand $\mathrm{O}_{2} \mathrm{CC}_{2} \mathrm{~F}_{5}{ }^{-}$anion. This ion exists as a stable non-radical anion, but its further dissociation has been detected. The presence of negative charge can affect the central carbon of the pentafluoropropionate, which leads to a loss of a fluorine atom. In fact, the $\mathrm{O}_{2} \mathrm{CC}_{2} \mathrm{~F}_{4}{ }^{-\bullet}$ anion represents the most abundant product among the ions from ligand dissociation. Finally, we have observed the formation of $\mathrm{C}_{2} \mathrm{~F}_{5}{ }^{-}$as the result of the carbon dioxide dissociation from $\mathrm{O}_{2} \mathrm{CC}_{2} \mathrm{~F}_{5}{ }^{-}$. In addition a slight shift of resonance maxima can be observed, which can represent a second resonance and/or a significant contribution of higher vibrational modes for an effective dissociation. In the case of $\left[\mathrm{Cu}_{2}\left(\mu-\mathrm{O}_{2} \mathrm{CC}_{2} \mathrm{~F}_{5}\right)_{4}\right]$, the contribution of higher excited states is significant, especially for a resonance at an incident electron energy $\approx 4.4 \mathrm{eV}$. This higher energy resonance could have its origin on a pentafluoroethyl substituent for $\left[\mathrm{Cu}_{2}(\mu\right.$ $\left.\left.\mathrm{O}_{2} \mathrm{CC}_{2} \mathrm{~F}_{5}\right)_{4}\right]$ exclusively leading to the dissociation of the $\mathrm{C}_{2} \mathrm{~F}_{5}{ }^{-}$ ion directly from TNI. The position of the resonance agrees with the formation of $\mathrm{C}_{2} \mathrm{~F}_{5}{ }^{-}$anion from $\mathrm{C}_{2} \mathrm{~F}_{6}$ molecule, its maximum cross section is here located at a similar energy of $4.8 \mathrm{eV}$ [53]. The presence of $\mathrm{EtNH}_{2}$ or $t-\mathrm{BuNH}_{2}$ in the com- plex closes this channel and the $\mathrm{C}_{2} \mathrm{~F}_{5}{ }^{-}$anion is formed only via the single particle resonance at almost $0 \mathrm{eV}$.

\section{Conclusion}

This article presents an investigation of the fragmentation following electron impact ionization of and electron attachment to four copper(II) carboxylate complexes.

Regarding electron impact ionization, the cross sections for formation of the parent molecular ions were very weak. Therefore, PES experiment have been performed for $\left[\mathrm{Cu}_{2}\left(\mathrm{EtNH}_{2}\right)_{2}(\mu-\right.$ $\left.\left.\mathrm{O}_{2} \mathrm{CC}_{2} \mathrm{~F}_{5}\right)_{4}\right]$ and $\left[\mathrm{Cu}_{2}\left(s-\mathrm{BuNH}_{2}\right)_{2}\left(\mu-\mathrm{O}_{2} \mathrm{CC}_{2} \mathrm{~F}_{5}\right)_{4}\right]$ to determine the ionization energies as $9.3 \mathrm{eV}$ for both compounds. Appearance energies show lower thresholds for loss of a ligand pair as compared to for loss of single ligands. This effect is quite obvious for $\left[\mathrm{Cu}_{2}\left(\mu-\mathrm{O}_{2} \mathrm{CC}_{2} \mathrm{~F}_{5}\right)_{4}\right]$, where $A E\left(\mathrm{Cu}_{2}\left(\mathrm{O}_{2} \mathrm{CC}_{2} \mathrm{~F}_{5}\right)_{3}{ }^{+}\right)=11.4 \mathrm{eV}, A E\left(\mathrm{Cu}_{2}\left(\mathrm{O}_{2} \mathrm{CC}_{2} \mathrm{~F}_{5}\right)_{2}^{+\bullet}\right)=$ $9.7 \mathrm{eV}$, and $A E\left(\mathrm{Cu}_{2}\left(\mathrm{O}_{2} \mathrm{CC}_{2} \mathrm{~F}_{5}\right)^{+}\right)=11.7 \mathrm{eV}$. The fragmentation of the ligand is also observed and comparable with respect to the suitable amine or carboxylic acid. The observation of the metallated ions containing both ligand types, e.g., $\left[\mathrm{Cu}_{2}\left(\mathrm{O}_{2} \mathrm{CC}_{2} \mathrm{~F}_{5}\right)\left(\mathrm{RNH}_{2}\right)\right]^{+},\left[\mathrm{Cu}_{2}\left(\mathrm{O}_{2} \mathrm{CC}_{2} \mathrm{~F}_{5}\right)_{3}\left(\mathrm{RNH}_{2}\right)_{2}\right]^{+}$confirmed whole complex molecules evaporation. However, in the case of the $\left[\mathrm{Cu}_{2}\left(\mathrm{EtNH}_{2}\right)_{2}\left(\mu-\mathrm{O}_{2} \mathrm{CC}_{2} \mathrm{~F}_{5}\right)_{4}\right]$ complex a partial amine loss occurred. The substantial production of free $\mathrm{Cu}^{+}$was detected only for $\left[\mathrm{Cu}_{2}\left(\mu-\mathrm{O}_{2} \mathrm{CC}_{2} \mathrm{~F}_{5}\right)_{4}\right]$ molecule, and a very weak production for $\left[\mathrm{Cu}_{2}\left(\mathrm{EtNH}_{2}\right)_{2}\left(\mu-\mathrm{O}_{2} \mathrm{CC}_{2} \mathrm{~F}_{5}\right)_{4}\right]$ complex. For the remaining two complexes we did not detect any $\mathrm{Cu}^{+}$ions. Therefore, we conclude that $\left[\mathrm{Cu}_{2}\left(\mu-\mathrm{O}_{2} \mathrm{CC}_{2} \mathrm{~F}_{5}\right)_{4}\right]$ can efficiently decompose to $\mathrm{Cu}^{+}$ion via electron impact in FEBID. The amine ligand introduction decreased the evaporation temperature but unfortunately suppressed the copper ion formation. On the other hand, this phenomenon can be useful for the "halo" effect limitation in FEBID processes.

Regarding electron attachment, we have registered the first spectra of negative ions for copper carboxylates compounds. Comparable negative ions are formed for all investigated molecules. The electron attachment processes occur mainly at incident electron energy close to $0 \mathrm{eV}$, through single particle resonances but specific fragments are also formed with smaller intensity through higher-lying resonances. In all cases (for $\left[\mathrm{Cu}_{2}(s-\right.$ $\left.\mathrm{BuNH}_{2}\right)_{2}\left(\mu-\mathrm{O}_{2} \mathrm{CC}_{2} \mathrm{~F}_{5}\right)_{4}$ ] only a week signal was observed), dissociative electron attachment generates the $\mathrm{Cu}_{2}\left(\mathrm{O}_{2} \mathrm{CC}_{2} \mathrm{~F}_{5}\right)_{4}{ }^{-}$anion. Dissociation causes the splitting of molecules into two almost equal fragments and thus formation of the $\mathrm{Cu}\left(\mathrm{O}_{2} \mathrm{CC}_{2} \mathrm{~F}_{5}\right)_{2}{ }^{-}$anion. This ion is dominant in the case of $\left[\mathrm{Cu}_{2}\left(\mu-\mathrm{O}_{2} \mathrm{CC}_{2} \mathrm{~F}_{5}\right)_{4}\right]$ but not as pronounced when the amine is coordinated. The formation of the negative ion of the carboxylate ligand $\mathrm{O}_{2} \mathrm{CC}_{2} \mathrm{~F}_{5}{ }^{-}$was detected together with additional dissociation fragments $\mathrm{O}_{2} \mathrm{CC}_{2} \mathrm{~F}_{4}{ }^{-\bullet}$ and $\mathrm{C}_{2} \mathrm{~F}_{4}{ }^{-\bullet}$. Here, the gener- 
ation of the $\mathrm{O}_{2} \mathrm{CC}_{2} \mathrm{~F}_{4}^{-\bullet}$ anion represents the very stable and abundant structure.

\section{Experimental}

Investigation of electron induced processes was carried out by crossed electron and molecular beam experiments [54]. The electron beam was created by a trochoidal electron monochromator operating with energy resolution down to $100 \mathrm{meV}$ in the range $0-120 \mathrm{eV}$. In the case of low signals, which were either an inherent property of the sample or resulted from the effect of deposition of the sample on the monochromators electrodes, the electron resolution was reduced up to $300-500 \mathrm{meV}$. A molecular beam was created by sublimation/evaporation of solid/gel samples into a small chamber. The chamber is connected with a main reaction chamber by small capillary, which creates a molecular beam that perpendicularly collides with the electron beam. Ionic products are then forced by a weak electric field into the ion optics of the quadrupole mass spectrometer. After separation of the products with different mass-to-charge ratios $(\mathrm{m} / \mathrm{z})$ the ions are detected by an electron multiplier. A constant electron energy of $70 \mathrm{eV}$ was applied to register the mass spectra, i.e., the ion intensity as function of the $\mathrm{m} / \mathrm{z}$ ratio of the measured ions. For a selected product (selected $\mathrm{m} / \mathrm{z}$ ratio) the ion yield dependences were then measured by varying the electron energy. In the case of the negative ions the recorded mass spectrum strongly depends on the electron energy due to a resonant character of attachment reaction.

For the measured cross section of electron ionization and dissociative ionization we can evaluate the threshold value of the corresponding ion formation by a fitting procedure using a modified Wannier law [55]. This value then represents an ionization potential or appearance energy of electron ionization or dissociative ionization respectively.

$$
\begin{aligned}
& S(\varepsilon)=b ; \varepsilon \leq A E, \\
& S(\varepsilon)=b+a(\varepsilon-A E)^{d} ; \varepsilon>A E,
\end{aligned}
$$

where $b$ represent background, $A E$ represent appearance (or ionization) energy, $\varepsilon$ is electron energy and $a, d$ are independent fitting parameters.

Calibration of the electron energy has been carried out by measurement of the ionization potential of Ar atoms and calibration to its known value $15.76 \mathrm{eV}$ [56] and with reference to the maximum of the electron attachment resonance on $\mathrm{SF}_{6}$ molecule at energy $\approx 0 \mathrm{eV}$ [57].

The studied complexes were heated up to temperature of 80-100 ${ }^{\circ} \mathrm{C}$, except for $\left[\mathrm{Cu}_{2}\left(\mu-\mathrm{O}_{2} \mathrm{CC}_{2} \mathrm{~F}_{5}\right)_{4}\right]$ where the tempera- ture range was $140-160^{\circ} \mathrm{C}$. Investigated molecules are characterized by relative high masses in range of 778 amu for $\left[\mathrm{Cu}_{2}(\mu-\right.$ $\left.\left.\mathrm{O}_{2} \mathrm{CC}_{2} \mathrm{~F}_{5}\right)_{4}\right]$ up to $924 \mathrm{amu}$ for $\left[\mathrm{Cu}_{2}\left(t-\mathrm{BuNH}_{2}\right)_{2}\left(\mu-\mathrm{O}_{2} \mathrm{CC}_{2} \mathrm{~F}_{5}\right)_{4}\right]$ or $\left[\mathrm{Cu}_{2}\left(s-\mathrm{BuNH}_{2}\right)_{2}\left(\mu-\mathrm{O}_{2} \mathrm{CC}_{2} \mathrm{~F}_{5}\right)_{4}\right]$. In the present experiment the intensity of ions detected with masses above approximately $m / z 300$ is reduced by the QMS. This can be avoided by decreasing the mass resolution (usually defined as the ratio of mass $m$ and full width at half maximum of the peak $\Delta m$ ) through changing the software parameter, which defines the resolution of the ion peak in the mass spectrum (see, for instance, Figure 2). Heavy ions can thus be detected. However, the position of the peak is then not measured precisely as the signal is broadened over several masses. High resolution measurements presented in the paper represent a peak FWHM $\approx 0.6 \mathrm{amu}$ and for medium resolution $\approx 1.6 \mathrm{amu}$. Measurements with low and very low resolution yield FWHM of peaks $\approx 4.5$ both, however with higher transmittance for the second one. (Regular $m / \Delta m$ ratio can be hardly evaluated due to dynamic resolution behavior.)

Photoelectron spectra (PES) were registered with a Perkin Elmer He I photoelectron spectrometer $[45,46]$. Photons with energy $22.21 \mathrm{eV}$ ionize the studied molecules in the gas phase. The photoelectrons depart from the chamber through a narrow slit and are analyzed with a cylindrical electrostatic analyzer. In the present measurements, electrons pass through an analyzer at the fixed predefined energy, while the potential of the analyzer is varied with respect to the target chamber. An energy calibration was carried out by measuring known argon and xenon ionization potentials.

\section{Materials}

Copper(II) carboxylate compounds with tert-butylamine of the general formula $\left[\mathrm{Cu}_{2}\left(t-\mathrm{BuNH}_{2}\right)_{2}\left(\mu-\mathrm{O}_{2} \mathrm{CR}\right)_{4}\right]$, where $\mathrm{R}=\mathrm{C}_{n} \mathrm{~F}_{2 n+1}, n=1-6$, were obtained in the reaction of copper(II) perfluorinated carboxylates with tert-butylamine, which was in situ generated from tert-butyl isocyanate [34]:

$$
\begin{aligned}
& 2\left[\mathrm{Cu}\left(\mathrm{O}_{2} \mathrm{CC}_{2} \mathrm{~F}_{5}\right)_{2}\right]+2 \mathrm{RNCO}+2 \mathrm{H}_{2} \mathrm{O} \\
& \rightarrow\left[\mathrm{Cu}_{2}\left(\mathrm{RNH}_{2}\right)_{2}\left(\mu-\mathrm{O}_{2} \mathrm{CC}_{2} \mathrm{~F}_{5}\right)_{4}\right]+2 \mathrm{CO}_{2} .
\end{aligned}
$$

The analogues procedure was applied for the synthesis of new complexes $\left[\mathrm{Cu}_{2}\left(\mathrm{EtNH}_{2}\right)_{2}\left(\mu-\mathrm{O}_{2} \mathrm{CC}_{2} \mathrm{~F}_{5}\right)_{4}\right]$ and $\left[\mathrm{Cu}_{2}(s-\right.$ $\left.\left.\mathrm{BuNH}_{2}\right)_{2}\left(\mu-\mathrm{O}_{2} \mathrm{CC}_{2} \mathrm{~F}_{5}\right)_{4}\right]$.

Copper(II) carboxylate $\left[\mathrm{Cu}\left(\mathrm{O}_{2} \mathrm{CC}_{2} \mathrm{~F}_{5}\right)_{2}\right]$ was prepared as reported [58]. Ethyl isocyanate (98\%), sec-butyl isocyanate (s-BuNCO, 98\%), and acetonitrile (99.93\%) were purchased from Aldrich. All reagents were used as received. 


\section{Instrumentation for complexes characteristics}

The first mass spectra were detected with a Finnigan MAT 95 mass spectrometer, using electron ionization (EI) method over the temperature range $30-350{ }^{\circ} \mathrm{C}$. IR spectra were measured with a PerkinElmer Spectrum 2000 FTIR spectrometer and a Spectrum RXI PerkinElmer, using KBr plates (400-4000 $\mathrm{cm}^{-1}$ ). The $\mathrm{Cu}$ content was determined with a Varian Spectr AA-20 Plus spectrophotometer. The content of C and $\mathrm{H}$ was determined CHNS Elemental Analyser-Euro Vector model 3018.

The yield of the complexes synthesis was about $60 \%$. The results of elementary analyses and spectroscopic data for new compounds were following:

$\left[\mathbf{C u}_{\mathbf{2}}\left(\mathbf{E t N H}_{\mathbf{2}}\right)_{\mathbf{2}}\left(\boldsymbol{\mu}-\mathrm{O}_{\mathbf{2}} \mathbf{C C}_{\mathbf{2}} \mathbf{F}_{\mathbf{5}}\right)_{\mathbf{4}}\right] \mathrm{C}_{16} \mathrm{H}_{14} \mathrm{Cu}_{2} \mathrm{~F}_{20} \mathrm{~N}_{2} \mathrm{O}_{8}$ (calc./ found) $\% \mathrm{Cu} 14.6 / 14.2$, C 22.1/22.1, $\mathrm{H} 1.63 / 2.41$, EIMS $T=58{ }^{\circ} \mathrm{C}(\mathrm{m} / z, \mathrm{RI} \%) \mathrm{C}_{2} \mathrm{H}_{7} \mathrm{~N}^{+\bullet}(45,5) ; \mathrm{Cu}_{2}\left(\mathrm{O}_{2} \mathrm{CC}_{2} \mathrm{~F}_{5}\right)^{+}(289$, 100); $\mathrm{Cu}_{2}\left(\mathrm{EtNH}_{2}\right)\left(\mathrm{O}_{2} \mathrm{CC}_{2} \mathrm{~F}_{5}\right)^{+}(334,3) ; \mathrm{Cu}_{2}\left(\mathrm{O}_{2} \mathrm{CC}_{2} \mathrm{~F}_{5}\right)_{2}^{+}(452$, 40); $\mathrm{Cu}_{2}\left(\mathrm{EtNH}_{2}\right)_{2}\left(\mathrm{O}_{2} \mathrm{CC}_{2} \mathrm{~F}_{5}\right)_{3}{ }^{+}(705,4)$, IR (KBr): , 3244, 3075, 2993, 2835, 2738, 2624, 2528, 2087, 1675, 1531, 1479, $1462,1413,1326,1212,1161,1030,821,799,733,585,541$, $422 \mathrm{~cm}^{-1}$.

$\left[\mathrm{Cu}_{\mathbf{2}}\left(\mathbf{s}-\mathrm{BuNH}_{\mathbf{2}}\right)_{\mathbf{2}}\left(\boldsymbol{\mu}-\mathrm{O}_{\mathbf{2}} \mathbf{C C}_{\mathbf{2}} \mathbf{F}_{\mathbf{5}}\right)_{\mathbf{4}}\right] \mathrm{C}_{20} \mathrm{H}_{22} \mathrm{Cu}_{2} \mathrm{~F}_{20} \mathrm{~N}_{2} \mathrm{O}_{8}$ (calc./ found) $\% \mathrm{Cu} 13.7 / 14.2, \mathrm{C} 26.0 / 25.4, \mathrm{~N} 2.4 / 3.8, \mathrm{H} \mathrm{2.4/3.7}$, EIMS $T=145^{\circ} \mathrm{C}(\mathrm{m} / \mathrm{z}, \mathrm{RI} \%) \mathrm{C}_{2} \mathrm{H}_{5} \mathrm{~N}^{+} / \mathrm{CO}_{2}{ }^{+\bullet} 44,100 ; \mathrm{C}_{3} \mathrm{H}_{8} \mathrm{~N}^{+}$ 58, 14; $\mathrm{C}_{2} \mathrm{~F}_{4}^{+\bullet} 100,41 ; \mathrm{C}_{2} \mathrm{~F}_{5}{ }^{+} 119,32 ; \mathrm{Cu}\left(\mathrm{s}-\mathrm{BuNH}_{2}\right)^{+} 136,2$; $\mathrm{Cu}_{2} \mathrm{~F}^{+} 145,5 ; \mathrm{Cu}_{2}\left(\mathrm{O}_{2} \mathrm{CC}_{2} \mathrm{~F}_{5}\right)^{+} 289,33 ; \mathrm{Cu}_{2}\left(\mathrm{O}_{2} \mathrm{CC}_{2} \mathrm{~F}_{5}\right)_{2}{ }^{+\bullet} 452$, 13; $\mathrm{Cu}_{2}\left(\mathrm{O}_{2} \mathrm{CC}_{2} \mathrm{~F}_{5}\right)_{3}\left(s-\mathrm{BuNH}_{2}\right)_{2}{ }^{+} 761$, 2; IR (KBr): 3240, 3121, 2980, 2945, 2892, 2747, 2655, 2567, 1678, 1612, 1518, 1489, $1465,1419,1327,1213,1164,1033,823,775,733,586,540$, $483,448 \mathrm{~cm}^{-1}$.

\section{Acknowledgements}

This work was conducted within the framework of the COST action CM1301 (CELINA). The precursors studies were supported by Nicolaus Copernicus University in Torun (Statute Research no.103). Financing of this work was by the Slovak Grant Agency VEGA 1/0733/17. This work was supported by the Slovak Research and Development Agency, project Nr. APVV-15-0580. This project has received funding from the European Union's Horizon 2020 research and an innovation programme under a grant agreement No 692335.

\section{References}

1. Kodas, T. T.; Hampden-Smith, M. J., Eds. The Chemistry of Metal CVD; John Wiley \& Sons: New York, NY, U.S.A., 2008. doi:10.1002/9783527615858

2. Utke, I.; Hoffmann, P.; Melngailis, J. J. Vac. Sci. Technol., B 2008, 26, 1197. doi:10.1116/1.2955728
3. Utke, I.; Gölzhäuser, A. Angew. Chem., Int. Ed. 2010, 49, 9328. doi:10.1002/anie.201002677

4. Hagen, C. W. Appl. Phys. A 2014, 117, 1599. doi:10.1007/s00339-014-8847-8

5. Bret, T.; Hofmann, T.; Edinger, K. Appl. Phys. A 2014, 117, 1607. doi:10.1007/s00339-014-8601-2

6. Koops, H. W. P.; Weiel, R.; Kern, D. P.; Baum, T. H. J. Vac. Sci. Technol., B 1988, 6, 477. doi:10.1116/1.584045

7. Nicholas, A. R.; Carlos, M. G.; Jason, D. F.; Philip, D. R. Nanotechnology 2013, 24, 415301. doi:10.1088/0957-4484/24/41/415301

8. Gazzadi, G. C.; Mulders, H.; Trompenaars, P.; Ghirri, A.; Affronte, M.; Grillo, V.; Frabboni, S. J. Phys. Chem. C 2011, 115, 19606. doi:10.1021/jp206562h

9. Córdoba, R.; Sesé, J.; De Teresa, J. M.; Ibarra, M. R. Microelectron. Eng. 2010, 87, 1550. doi:10.1016/j.mee.2009.11.027

10. Engmann, S.; Stano, M.; Matejčík, Š.; Ingólfsson, O. Angew. Chem., Int. Ed. 2011, 50, 9475. doi:10.1002/anie.201103234

11. Engmann, S.; Stano, M.; Papp, P.; Brunger, M. J.; Matejčík, Š.; Ingólfsson, O. J. Chem. Phys. 2013, 138, 044305. doi:10.1063/1.4776756

12. Engmann, S.; Ómarsson, B.; Lacko, M.; Stano, M.; Matejčík, Š.; Ingólfsson, O. J. Chem. Phys. 2013, 138, 234309. doi:10.1063/1.4810877

13. Wnorowski, K.; Stano, M.; Matias, C.; Denifl, S.; Barszczewska, W.; Matejčík, Š. Rapid Commun. Mass Spectrom. 2012, 26, 2093. doi:10.1002/rcm.6324

14. May, O.; Kubala, D.; Allan, M. Phys. Chem. Chem. Phys. 2012, 14, 2979. doi:10.1039/C2CP23268E

15. Friedman, J. F.; Miller, T. M.; Friedman-Schaffer, J. K.; Viggiano, A. A.; Rekha, G. K.; Stevens, A. E. J. Chem. Phys. 2008, 128, 104303. doi:10.1063/1.2831391

16. Friedman, J. F.; Stevens, A. E.; Miller, T. M.; Viggiano, A. A. J. Chem. Phys. 2006, 124, 224306. doi:10.1063/1.2202851

17. Lacko, M.; Papp, P.; Wnorowski, K.; Matejčík, Š. Eur. Phys. J. D 2015, 69, 84. doi:10.1140/epjd/e2015-50721-8

18. Papp, P.; Engmann, S.; Kučera, M.; Stano, M.; Matejčík, Š.; Ingólfsson, O. Int. J. Mass Spectrom. 2013, 356, 24. doi:10.1016/j.jims.2013.09.011

19. Wnorowski, K.; Stano, M.; Barszczewska, W.; Jówko, A.; Matejčík, Š. Int. J. Mass Spectrom. 2012, 314, 42. doi:10.1016/j.jjms.2012.02.002

20. Schaefer, J.; Hoelzl, J. Thin Solid Films 1972, 13, 81. doi:10.1016/0040-6090(72)90158-7

21. Knights, A. P.; Coleman, P. G. Appl. Surf. Sci. 1995, 85, 43. doi:10.1016/0169-4332(94)00306-8

22. Thorman, R. M.; Kumar T. P., R.; Fairbrother, D. H.; Ingólfsson, O. Beilstein J. Nanotechnol. 2015, 6, 1904. doi:10.3762/bjnano.6.194

23. Allan, M. J. Chem. Phys. 2011, 134, 204309. doi:10.1063/1.3594206

24. Kodas, T. T.; Hampden-Smith, M. J., Eds. The Chemistry of Metal CVD; VCH: Weinheim, Germany, 1994; pp 20-30. doi:10.1002/9783527615858 Also pp 175-242.

25. Hoshino, M.; Kasai, K.; Komeno, J. Jpn. J. Appl. Phys., Part 11992 , 31, 4403. doi:10.1143/jjap.31.4403

26. Murarka, S. P. Mater. Sci. Eng. 1997, 19, 87.

27. Grodzicki, A.; Łakomska, I.; Piszczek, P.; Szymańska, I.; Szłyk, E. Coord. Chem. Rev. 2005, 249, 2232. doi:10.1016/j.ccr.2005.05.026

28. Bhanushali, S.; Ghosh, P.; Ganesh, A.; Cheng, W. Small 2015, 11 , 1232. doi:10.1002/smll.201402295 
29. Szkudlarek, A.; Vaz, A. R.; Zhang, Y.; Rudkowski, A.; Kapusta, C.; Erni, R.; Moshkalev, S.; Utke, I. Beilstein J. Nanotechnol. 2015, 6, 1508. doi:10.3762/bjnano.6.156

30. Luisier, A.; Utke, I.; Bret, T.; Cicoira, F.; Hauert, R.; Rhee, S.-W.; Doppelt, P.; Hoffmann, P. J. Electrochem. Soc. 2004, 151, C590. doi:10.1149/1.1779335

31. Warneke, J.; Rohdenburg, M.; Zhang, Y.; Orszagh, J.; Vaz, A.; Utke, I.; De Hosson, J. T. M.; Dorp, W. F.; Swiderek, P. J. Phys. Chem. C 2016, 120, 4112. doi:10.1021/acs.jpcc.5b12184

32. Kopyra, J.; Koenig-Lehmann, C.; Bald, I.; Illenberger, E. Angew. Chem., Int. Ed. 2009, 48, 7904. doi:10.1002/anie.200903874

33. Lin, D. C. K.; Westmore, J. B. Can. J. Chem. 1973, 51, 2999. doi:10.1139/v73-446

34. Szymańska, I. B. Polyhedron 2013, 50, 200. doi:10.1016/j.poly.2012.10.046

35. Engmann, S.; Stano, M.; Matejčík, Š.; Ingólfsson, O. Phys. Chem. Chem. Phys. 2012, 14, 14611. doi:10.1039/c2cp42637d

36. Utke, I.; Friedli, V.; Purrucker, M.; Michler, J. J. Vac. Sci. Technol., B: Microelectron. Nanometer Struct.--Process., M eas., Phenom. 2007, 25, 2219. doi:10.1116/1.2789441

37. Warneke, J.; Van Dorp, W. F.; Rudolf, P.; Stano, M.; Papp, P.; Matejčík, Š.; Borrmann, T.; Swiderek, P. Phys. Chem. Chem. Phys. 2015, 17, 1204. doi:10.1039/C4CP04239E

38. Piszczek, P.; Szymańska, I. B.; Talik, E.; Heimann, J. Chem. Vap. Deposition 2013, 19, 251. doi:10.1002/cvde.201207049

39. Nakagawa, H.; Kani, Y.; Tsuchimoto, M.; Ohba, S.; Matsushima, H.; Tokii, T. Acta Crystallogr., Sect. C: Cryst. Struct. Commun. 2000, 56, 12. doi:10.1107/S0108270199012147

40. Zhang, J.; Hubert-Pfalzgraf, L. G.; Luneau, D. Polyhedron 2005, 24 , 1185. doi:10.1016/j.poly.2005.04.009

41. Ozarowski, A.; Szymańska, I. B.; Muzioł, T.; Jezierska, J. J. Am. Chem. Soc. 2009, 131, 10279. doi:10.1021/ja902695y

42. Page, R. H.; Larkin, R. J.; Shen, Y. R.; Lee, Y. T. J. Chem. Phys. 1988, 88, 2249. doi:10.1063/1.454058

43. Berkowitz, J.; Ellison, G. B.; Gutman, D. J. Phys. Chem. 1994, 98, 2744. doi:10.1021/j100062a009

44. Spectral database for organic compounds SDBS, National Institute of Advanced Industrial Science and Technology. Gaithersburg, MD, U.S.A.http://sdbs.db.aist.go.jp/sdbs/cgi-bin/direct_frame_top.cgi (accessed Aug 1, 2017)

45. Dressler, R.; Neuhaus, L.; Allan, M. J. Electron Spectrosc. Relat. Phenom. 1983, 31, 181. doi:10.1016/0368-2048(83)80021-8

46. Ibănescu, B. C.; Allan, M. Phys. Chem. Chem. Phys. 2008, 10, 5232. doi:10.1039/b806578k

47. Böhler, E.; Warneke, J.; Swiderek, P. Chem. Soc. Rev. 2013, 42, 9219. doi:10.1039/c3cs60180c

48. NIST WebBook Chemie, NIST Standard Reference Database Number 69. U.S. Secretary of Commerce, National Institute of Standards and Technology: Gaithersburg, MD, U.S.A.http://webbook.nist.gov/chemistry/ (accessed Aug 1, 2017).

49. Dibeler, V. H.; Reese, R. M.; Mohler, F. L. J. J. Res. Natl. Bur. Stand. (U. S.) 1956, 57, 113. doi:10.6028/jres.057.014

50. Fisher, E. R.; Armentrout, P. B. Int. J. Mass Spectrom. Ion Processes 1990, 101, R1-R6. doi:10.1016/0168-1176(90)80023-V

51. Noutary, C. J. J. Res. Natl. Bur. Stand., Sect. A 1968, 72A, 479.

52. Wang, L.-S.; Reutt, J. E.; Lee, Y. T.; Shirley, D. A. J. Electron Spectrosc. Relat. Phenom. 1988, 47, 167. doi:10.1016/0368-2048(88)85010-2
53. Christophorou, L. G.; Olthoff, J. K. J. Phys. Chem. Ref. Data 1998, 27, 1. doi:10.1063/1.556016

54. Stano, M.; Matejcik, S.; Skalny, J. D.; Märk, T. D. J. Phys. B 2003, 36, 261. doi:10.1088/0953-4075/36/2/307

55. Wannier, G. H. Phys. Rev. 1953, 90, 817. doi:10.1103/PhysRev.90.817 56. Lide, D. R., Ed. Handb. Chem. Phys.; CRC Press: Boca Raton, FL, U.S.A., 1992; $p 10$.

57. Christophorou, L. G.; Olthoff, J. K. J. Phys. Chem. Ref. Data 2000, 29, 267. doi:10.1063/1.1288407

58. Szłyk, E.; Szymańska, I. Polyhedron 1999, 18, 2941. doi:10.1016/S0277-5387(99)00199-0

\section{License and Terms}

This is an Open Access article under the terms of the Creative Commons Attribution License

(http://creativecommons.org/licenses/by/4.0), which permits unrestricted use, distribution, and reproduction in any medium, provided the original work is properly cited.

The license is subject to the Beilstein Journal of

Nanotechnology terms and conditions:

(https://www.beilstein-journals.org/bjnano)

The definitive version of this article is the electronic one which can be found at: doi:10.3762/bjnano.9.38 